\title{
Inherited Control and Firm Performance
}

\author{
FRANCISCO PÉREZ-GONZÁLEZ*
}

\begin{abstract}
I use data from chief executive officer (CEO) successions to examine the impact of inherited control on firms' performance. I find that firms where incoming CEOs are related to the departing CEO, to a founder, or to a large shareholder by either blood or marriage underperform in terms of operating profitability and market-tobook ratios, relative to firms that promote unrelated CEOs. Consistent with wasteful nepotism, lower performance is prominent in firms that appoint family CEOs who did not attend "selective" undergraduate institutions. Overall, the evidence indicates that nepotism hurts performance by limiting the scope of labor market competition. JEL G32, G34, L25, M13
\end{abstract}

\begin{abstract}
"One of the strongest natural proofs of the folly of hereditary right in kings, is, that nature disapproves it, otherwise she would not so frequently turn it into ridicule by giving mankind an ass for a lion."

Thomas Paine ${ }^{1}$
\end{abstract}

"The only reason I was on the payroll is because I was the son of the boss."

John H. Tyson, CEO of Tyson Foods, Inc. ${ }^{2}$

The promotion of one's kin to a key corporate or governmental position is often tainted with controversy. In the United States, favoritism based on relationships rather than on merit has long been questioned on ethical and practical bases. ${ }^{3}$ Recent discussions related to public sector appointments underscore these concerns. ${ }^{4}$ Yet, despite the widespread debate there has been little systematic economic analysis to determine the impact of family successions on the performance of firms or institutions that experience them. ${ }^{5}$

\footnotetext{
* Columbia University, Graduate School of Business, 3022 Broadway, Room 422, New York, NY, 10027. Email: fp2010@columbia.edu. I thank three anonymous referees for very helpful and detailed comments. I also thank Dan Altman, Ken Ayotte, Marianne Bertrand, Rajeev Cherukupalli, David Denis, Liran Einav, Martin Feldstein, Caroline Hoxby, Gur Huberman, Larry Katz, Nuria Mas, Alejandro Micco, David Robinson, Emmanuel Saez, Antoinette Schoar, Andrei Shleifer, Phil Strahan, Daniel Wolfenzon and many seminar participants. I am grateful to Michael Brown, Stephane Goldsand and Emilio Pineda for their help in assembling the data for this paper. An earlier version of this paper circulated under the title “Does Inherited Control Hurt Firm Performance?”All errors are my own.

${ }^{1}$ Paine (1776), italics in the original, page 17 in (2004) reprint.

2 From Nicholas Stein’s (2002) article “Son of a chicken man,” Fortune, May 2002, page 206.

3 Excerpts from Perrin Stryker's (1957) Fortune's article "Would you hire your son?" illustrate the debate: "Nepotism is immoral...relatives made this company what it is today...is it [nepotism] un-American?" Fortune, March 1937, page 122.

${ }^{4}$ See for example, Mark Thompson, Karen Tumulty, and Mike Allen (2005) Time's story "How many more Mike Browns are out there?” or The Economist's October 1, 2005, cover story.

${ }^{5}$ The only study that I am aware of is Brian F. Smith and Ben Amoako-Adu (1999), who examine performance effects of senior management turnover in a sample of 124 Canadian family-controlled firms.
} 
This omission is particularly surprising in light of recent evidence that highlights the pervasiveness and concentration of family ownership in publicly traded corporations (Rafael La Porta, Florencio Lopez de Silanes, Andrei Shleifer, and Robert W. Vishny (1999); Randall K. Morck, David A. Stangeland, and Bernard Yeung (2000); Stijn Claessens, Simeon Djankov, and Larry H. P. Lang (2002); Mara Faccio and Lang (2002); and Ronald C. Anderson and David M. Reeb (2003)), and because families can potentially use their voting power to promote a family member to the top management position despite the opposition of minority investors.

The main argument against family successions in publicly traded firms is that competitive contests for top executive positions would rarely result in a family chief executive officer (CEO). To use Warren Buffett's analogy, those firms that pick executives from the small pool of family heirs would be "choosing the 2020 Olympic team by picking the eldest sons of the gold-medal winners of the 2000 Olympics." ${ }^{\text {, }}$ Unrelated CEOs, in contrast, represent a self-selected group of highly driven individuals who experience the permanent pressure to perform from the labor markets (Eugene F. Fama (1980)). Consistent with this view, recent models of family firms assume the outright superiority of unrelated CEOs (Mike Burkart, Fausto Panunzi, and Andrei Shleifer (2003); Utpal Bhattacharya and B. Ravikumar (2005)).

Yet family successions might have a beneficial impact on performance. Family CEOs are argued to be stewards of their firms (James H. Davis, F. David Schoorman and Lex Donaldson (1997)). They may enhance performance by reducing agency problems (Anderson and Reeb (2003)), facilitating firm-specific investments, or by easing cooperation and the transmission of knowledge within organizations (Louis B. Barnes and Simon A. Hershon (1976)). Furthermore, family heirs have also been argued to have a long-term focus that unrelated chief executives lack (Adrian Cadbury (2000)).

In this paper I investigate the impact of inherited CEO positions on the performance of publicly traded U.S. corporations. I use data from 335 management transitions in firms with concentrated ownership or founding family involvement. In this sample, 122 successions (36.4 percent) are classified as involving a "family" CEO when the incoming chief executive was related by blood or marriage to the departing CEO, to the founder, or to the largest shareholder of the corporation. The remaining 213 observations are classified as "unrelated" successions.

\footnotetext{
${ }^{6}$ From David C. Johnston's (2001), New York Times' story “Dozens of rich Americans join in fight to retain the estate tax," New York Times, February 14, 2001, page C.1.
} 
Using an event-study analysis, I examine the impact on firm market value of naming family and unrelated CEOs. I find that only unrelated promotions are associated with positive abnormal returns, both upon announcement and in the three years after appointments. This result, however, is shown to be largely explained by the promotion of external CEOs. ${ }^{7}$ Given that inference from event-studies around succession decisions is problematic when, for example, the identity of the incoming CEO is long anticipated or when CEO transitions by themselves provide information on firms' prospects, the bulk of the empirical analysis in the paper focuses on changes in accounting-based measures of performance around CEO successions.

An advantage of using within-firm variation in performance is that it allows me to control for time-invariant characteristics that might jointly affect a firm's prospects and its decision to appoint a family CEO. I evaluate firm performance using operating return on assets, net income to assets, and market-to-book ratios. ${ }^{8}$ In assessing differential performance around transitions, I adjust these variables using industry-and industry- and performance-matched benchmarks, to control for potential mean-reversion in accounting variables (Brad M. Barber and John D. Lyon (1996)).

Overall, the findings of this paper provide empirical support to the idea that a number of firms in this sample promote CEOs based on family ties rather than on merit. First, family CEOs are, on average, eight years younger than unrelated CEOs at the time of their appointment. Second, I find that firms that appoint family CEOs significantly underperform relative to firms that promote unrelated CEOs: operating return on assets (market-to-book ratios) is 14 (16) percent lower within three years of a transition.

I further test for nepotism by examining whether the undergraduate institution attended by family CEOs predicts subsequent differences in firm performance. If attending a selective college provides a valuable signal of ability (Michael A. Spence (1974)), then those family heirs who hold this signal should be expected to perform better than other family CEOs. As a result, appointments without merit should be relatively more common among those family heirs that despite their family background, did not attend selective institutions. To identify which colleges were likely to be “selective,” I use Barron’s Profiles of American Colleges (1980).

\footnotetext{
${ }^{7}$ A CEO is classified as external when he or she was hired from outside the firm within a year prior to succession.

${ }^{8}$ I examine differences in operating return on assets following the CEO turnover literature (David J. Denis and Diane K. Denis (1995); Mark R. Huson, Paul Malatesta, and Robert Parrino (2004)), and differences in market-tobook ratios (average $Q$ ) as in the ownership and family firm literatures (Morck et al. (1988b); Anderson and Reeb (2003); Villalonga and Amit (2004)).
} 
The results are striking. I find that firms with a family CEO who did not attend a selective college, ${ }^{9}$ which occurred in 54 cases (45 percent of family CEOs), dramatically underperform: operating return on assets and market-to-book ratios are around 25 percent lower within three years of the succession relative to firms that promote unrelated CEOs. Moreover, these remarkable and statistically significant differences in performance are not observed in firms with family CEOs who attended selective undergraduate institutions. Additionally, the college attended by non-family managers does not predict subsequent declines in firm performance, as expected if non-family CEOs had to demonstrate their competence before getting the top job.

The patterns described above are robust to the inclusion of an array of controls that have been found in the literature to affect CEO turnover decisions, such as pre-transition profitability and firm size, as well as board ownership, industry controls, and time trends. In addition, I find that the superior performance of unrelated relative to family CEOs is not associated with a greater tendency to fire workers or sell assets. I do, however, find that family-CEO firms, and in particular those that promote LSC-family heirs are associated with increases in firm production costs and lower sales growth.

Overall, my findings indicate that the costs of nepotism are large and that they are likely to be borne by minority investors who do not share in the private benefits of control. The estimated declines in market-to-book ratios relative to pre-succession market valuations and a long-run abnormal return analysis suggest that the private benefits of naming a family CEO are at least 15 percent of value, in line with estimates of the value of private benefits of control in other settings (Michael J. Barclay and Clifford G. Holderness (1989)).

The findings of this paper may be interpreted as indicative that managerial ability, as well as one's physical characteristics or earnings, tends to regress to the average of the population (Francis Galton (1886); Gary S. Becker and Nigel Tomes (1986); Casey B. Mulligan (1999)) or alternatively as supportive evidence of the "Carnegie Conjecture” (Douglas Holtz-Eakin, David Joulfaian, and Harvey S. Rosen (1993)), which emphasizes the disincentive effects caused by abundant wealth.

\footnotetext{
9 Hereafter, a "selective" college is an undergraduate institution classified as "very competitive" or better in Barron's (1980) profiles. In 1980, a total of 189 colleges that primarily considered applicants who ranked in the top 50 percent of their graduating high school class were classified as “very competitive” or better. Table 7 presents results for alternative measures of college selectivity.
} 
Finally, this paper also contributes to the growing literature on the performance effects of managerial turnover (David J. Denis and Diane K. Denis (1995); and Mark R. Huson, Paul Malatesta and Robert Parrino (2004)) by estimating the value of professional CEO talent in a setting where the counterfactual is provided by CEOs who are not chosen competitively. More generally, the evidence of this paper illustrates the virtue of contested elections relative to promotion processes where successors gain access to organizational posts by virtue of birth or through familial privilege.

The rest of the paper is organized as follows. Section I presents related literature. Section II describes the data and the definitions of family and unrelated successions used in this paper. Section III puts forth the empirical predictions if nepotism were at work in these CEO transitions. Section IV describes an event-study examining the effects of naming family and unrelated CEOs on stock returns. Section V presents the main results of this paper. Section VI examines alternative explanations for the empirical results described in Section V, and Section VII concludes.

\section{I. $\quad$ Related Literature}

Harold Demsetz and Kenneth Lehn (1985) and Andrei Shleifer and Robert Vishny (1986) have long shown that the Adolph Berle and Gardiner Means' (1932) view of firms with separated ownership and control is not a comprehensive description of publicly traded firms. Evidence of ownership concentration, especially around families, by La Porta et al. (1999) indicates that families control over 53 percent of publicly traded firms with at least $\$ 500$ million in market capitalization in 27 countries. Additional evidence of the prominent role of families in public firms has been provided by Morck et al. (2000) for Canada, by Claessens et al. (2002) for East Asian countries, and by Faccio and Lang (2002) for Western Europe. In the U.S., family ownership is present in 35 (37) percent of firms in the Standard and Poor's (Fortune) 500, where families hold an average of 18 (16) percent of shares (Anderson and Reeb (2003); and Belén Villalonga and Raphael Amit (2006)).

The theoretical predictions on the impact of family ownership and of family CEOs on performance are not unidirectional (Robert G. Donnelley (1964)). Families might reduce agency costs by concentrating substantial decision and cash-flow rights (Eugene F. Fama and Michael 
Jensen (1983)), or because family managers derive significant personal satisfaction from the success of the organization (Davis et al. (1997)). Also, family peer pressure, shame, or guilt (Eugene Kandel and Edward P. Lazear (1992)) could provide unique incentives for family members to exert effort. In this regard, Barnes and Hershon (1976) argue that most firms tend to rely more on family and personal psychology than on business logic. As a result, family executives might maintain the loyalty of other relevant stakeholders (Donnelley (1964)), which could in turn contribute to the long-term success of an organization.

Alternatively, the close collaboration of family members within a firm may hurt performance (Christopher Christiansen (1953); Elaine Kepner (1983)). Contradictions between family and business norms may generate conflicts in response to the allocation of management positions, executive pay, or other resources (Harry Levinson (1971); Barnes and Hershon (1976); and Ivan Lansberg (1983)). According to Lansberg (1983), "Founders often find themselves in the difficult position of having to choose between either hiring (or firing) an incompetent relative or breaking up their relationship with some part of the family." 10 These tensions tend to be particularly acute at the time of succession (Lansberg (1988)). ${ }^{11}$

To date, several studies have empirically examined the impact of founders and their families on performance. The evidence is mixed and inference is further complicated by the fact that firms’ family status or changes in this status are not random.

Bruce W. Johnson, Robert P. Magee, Nandu J. Nagarajan, and Harry A. Newman (1985) find that sudden deaths of founder CEOs are associated with stock price increases, which suggests that founder CEOs hindered performance. Yet Myron B. Slovin and Marie E. Sushka (1993), in analyzing deaths of large shareholders, find that founder status does not have a significant effect in explaining abnormal returns. They do, however, find that the death of CEOs with concentrated ownership is associated with positive abnormal returns and with higher corporate control contests, both consistent with entrenchment.

Morck et al. (1988b) find a positive and significant correlation between founding family management and market-to-book (M-B) ratios for young firms but a negative correlation for old firms in their sample. David Yermack (1996) finds that the presence of founding family CEOs is negatively correlated with M-B ratios. Daniel L. McConaughy, Michael C. Walker, Glenn V.

\footnotetext{
${ }^{10}$ Lansberg (1983), page 41.

${ }^{11}$ Craig E. Aronoff, Joseph H. Astrachan and John L. Ward (1996) argue that the three most important issues confronting the family business are succession, succession and succession.
} 
Henderson, Jr. and Chandra S. Mishra (1998) find a positive impact of founding family CEOs on M-B ratios. Morck et al. (2000) find lower operating performance for family CEOs who inherit their positions. Anderson and Reeb (2003) find a positive correlation between founding family ownership and firm profitability and M-B ratios, and conditional on family ownership, a positive correlation between these performance measures and family CEOs. Finally, Villalonga and Amit (2006) find that founding families enhance value only when founders are active as executives or directors of the corporation but hurt valuations in firms managed by descendant CEOs.

These previous studies have thus far ignored CEO successions, which is one crucial way in which families can affect performance and where the interests of insiders and those of minority shareholders are likely to differ. Insiders might prefer to elect CEOs who ex-ante represent an inferior match to the interest of non-controlling shareholders (Michael C. Jensen and William H. Meckling (1976)). The smaller the pool of acceptable CEOs for insiders, the larger the potential costs of this mismatch. This pool tends to be the smallest in the case of family CEOs.

Looking at CEO transitions, and thus at within-firm variation in performance has a further advantage: it allows us to control for time-invariant characteristics, observable or unobservable (such as brands or proprietary assets), that might affect families' decisions to name a family CEO, but are difficult to control for empirically in a purely cross-sectional setting.

The only study of which I am aware related to family management transitions and firm performance is Brian F. Smith and Ben Amoako-Adu (1999). This study uses data from 124 Canadian firms to examine the impact of senior management transitions (president, chief operating officer, chief executive officer, and chairman positions) on stock returns and operating performance. Of the 124 management changes, 49 involved a CEO transition, 18 of which were family and 31 unrelated. The authors find (1) that prior performance does not predict family appointments, (2) that family transitions are correlated with negative abnormal returns at the time of announcement but superior long-term returns relative to external managers, and (3) that family management is correlated with lower median return on assets (ROA).

Smith and Amoako-Adu's study, however, leaves several issues unresolved which this paper seeks to address. First, its small sample size, and the combination of several distinct management positions precludes inference on the differential qualities of family and unrelated CEOs. Second, the switching sign in returns over time for family and external CEOs does not 
lead to a clear reading on whether family or unrelated CEOs are superior. Third, the fact that their relative ROA analysis does not control for firm characteristics such as firm size, pretransition profitability, or board ownership, makes it hard to distinguish between firm or CEO traits.

In sum, despite the substantial debate surrounding family firms it is surprising how little we know about the specific mechanisms behind the correlations between family ownership or family management and performance. In the following sections, I test for the value of family and unrelated CEOs using stock return and accounting-based measures of performance.

\section{Data and Definitions of Family and Unrelated Successions}

\section{A. Sample Selection}

To test the impact of inherited control on firm performance I aimed at constructing a dataset where (1) concentrated ownership or family connections are likely to be important and (2) where "normal"-non-performance-related-CEO successions are expected to occur. Ideally one would like to follow all firms since inception and investigate their business histories. In this paper, however, I constructed the sample in the following way.

Starting with all U.S. non-financial, non-utility firms in COMPUSTAT in 1994 (the first year for which the Security and Exchange Commission's (SEC) Edgar database is available online), I impose three major restrictions on firms (sample construction is further detailed in Appendix A). First, to increase the likelihood of observing normal successions, firms have to have been founded prior to 1971 (a generation back). Second, to identify firms where control was likely to be inherited among kin, I require that, based on proxy statement information, they had at least one of the following: (a) an individual with at least five percent of ownership; (b) two or more individuals related by blood or marriage as directors, officers, or shareholders; or (c) a founder as an executive or director. Third, a management change needs to have occurred, as identified by a news search using the Dow Jones Inc. Factiva publications library between 1980 and 2001 for which matching financial data was available both before and after succession. I ultimately arrive at 335 firms, equivalent to 7.2 percent of all non-financial, non-utility firms in COMPUSTAT in 1994, and to 10.9 and 10.5 percent of its sales and market values, respectively. 
The requirement that firms have to have been active since 1970 introduces a survivor bias. Also, ownership and other requirements make the data of this paper unlikely to be representative of the universe of firms. The results of this paper are, therefore, only representative of the reported firms. These concerns do not a priori induce a bias towards finding a correlation between family or unrelated successions and their impact on post-transition performance.

\section{B. Family vs. Unrelated Successions}

In this paper I classify as "family successions" any management change where the new CEO was related by blood or marriage to: (a) the departing CEO, (b) the founder, or (c) a large shareholder. Other management transitions are classified as "unrelated". Based on this classification I identify 122 family and 213 unrelated successions. ${ }^{12}$

Table 1 illustrates the industry distribution of firms in the sample using the Fama-French 12-industry classification. ${ }^{13}$ As a benchmark for comparison, I report the share of firms per industry in COMPUSTAT in 1994 in Column IV. The largest differences relative to COMPUSTAT were found in Manufacturing, which accounts for 23.6 percent of firms in this paper relative to 15.4 percent therein, and in Health, Medical, and Equipment with 3.9 percent relative to 11.9 percent in COMPUSTAT. The industries with the largest number of observations are Manufacturing (79), Business Equipment (54), and Wholesale Retail and Some Services (52), while those with the smallest number of observations are Telephone and Television (6), Oil, Gas, and Coal Extraction (12), and Healthcare, Medical Equipment, and Drugs (13).

Table 1 shows that family successions in this sample were evenly distributed across industries. Family heirs were equivalent to 30.6 to 41.2 percent of CEO changes in industries with at least 14 observations, including Consumer Non-Durables, Consumer Durables, Manufacturing, Chemicals and Allied Products, Business Equipment, Wholesale Retail and Some Services, and Other Industries. Family heir successions were equivalent to 36.4 percent of all transitions.

\footnotetext{
${ }^{12}$ Table 6 examines changes in performance for alternative sub-samples based on ownership, board characteristics, family links, and for cases where the incoming CEO's name coincided with the firms'.

${ }^{13}$ Industry classification information was obtained from http://mba.tuck.dartmouth.edu/pages/faculty/ken.french/
} 
Examining the distribution of successions during the sample period, I find that only 29 of the 335 transitions occurred between 1980 and 1985, while 82, 137, and 87 transitions were identified between 1985 and 1990, 1990 and 1995, and 1995 and 2000, respectively. Of the 111 observations in the 1980 to 1990 period, 48 percent had a family CEO while only 31 percent of the 224 observations post-1990 had a family CEO. Within the setting of family firms, this trend is consistent with the overall evidence provided by Mark R. Huson, Robert Parrino, and Laura Starks (2001) who show an increase in the frequency of outside successions in the nineties.

Summary statistics are presented in Table 2 . The first row shows that the average age of new CEOs was 47.86 years. Interestingly, the average age of family heirs when they were promoted to the CEO position was as much as 8.15 years less than the average age of unrelated CEOs when they took over the job -42.68 versus 50.83 years. This difference is significant at the one-percent level. As reference, Huson et al. (2004) document that the average age of incoming CEOs in the annual Forbes compensation survey is 53 years. Note that while the prevalence of family successions in the sample is not necessarily surprising, since by construction this study was intended to over-sample these firms, the fact that family heirs were promoted at a younger age than other CEOs may indicate that the requirements to be a CEO differ for family members.

On average, incoming family CEOs hold larger shareholdings relative to unrelated CEOs. The average ownership of family CEOs prior transition was 11.2 percent versus 2.2 percent of unrelated CEOs. Likewise, board ownership concentration was larger for firms that observed family promotions, where boards held an average of 31.9 percent of the outstanding stock relative to 23.4 percent for firms that elected unrelated CEOs. Incoming CEOs' ownership seems to account for the difference in board ownership concentration across firms, as the difference in CEO and board ownership is around nine percentage points, significant at the one-percent level.

Summary statistics show that firms where control is passed within the family are far from the stereotypical "mom-and-pop stores." The average book value of assets and market value of equity in the year prior transition was equal to 1.1 and 1.2 billion (2002 dollars), respectively. Firms that promoted unrelated CEOs had average book value of assets and market value of equity of 1.4 and 1.7 billion (2002 dollars), respectively. Yet the difference for family and unrelated transitions in these two variables was not found to be significant at conventional levels. 
Measures of operating profitability show that family CEO firms are comparable to those that selected unrelated managers. Average unadjusted operating return on assets (OROA) was 14.1 and 13.9 percent for family and unrelated successions, respectively. ${ }^{14}$ Industry-adjusted OROA, which is calculated by subtracting the median OROA of the relevant industry (two-digit SIC code) and year, shows that firms in the sample, both family and unrelated, outperform other firms in their industries by 3.3 and 3.1 percent, respectively. The differences in OROA and industry-adjusted OROA are not statistically different from zero.

I also present industry- and performance-adjusted OROA and net income the year prior to transition. Industry and performance adjustments are calculated by subtracting the median of the relevant variable of a control group of firms with similar industry-adjusted performance. The control groups are created by dividing COMPUSTAT firms into deciles sorted by the relevant variable (e.g. industry-adjusted OROA) the year prior transition. The yearly median of the relevant group of firms (ex-event) is then used as the control for each firm-year observation. Table 2 shows that the above-described correction yields industry- and performance-adjusted OROA that are not statistically different from zero and whose across-successions differences are also not significant at conventional levels. Similarly, industry-and performance-adjusted net income ratios also yield comparable profitability for both groupings. Market-to-book ratios also suggest that the two groups of firms are comparable prior to transitions. ${ }^{15}$ The average M-B ratio was 1.481 and 1.485 for firms that promote family and unrelated CEOs, respectively.

In sum, observable firm characteristics suggest that family and unrelated CEO firms in the sample are comparable before CEO transitions. The fact that size is not statistically different for firms that elect family CEOs might be the result of the sample construction of the paper and, as such, might not be informative of the relative size of family-CEO firms in the economy.

The last row in Table 2 shows evidence in line with Morck et al. (2000). On average, spending on research and development $(\mathrm{R} \& \mathrm{D})$ is statistically lower for firms that appointed family CEOs. Firms that promoted unrelated CEOs spent 4.6 percent of assets on R\&D while those that appointed a family heir only spent 2.9 percent, a difference of 1.8 percentage points

\footnotetext{
${ }^{14}$ Operating income (COMPUSTAT item 13) relative to the book value of assets (COMPUSTAT item 6).

${ }^{15} \mathrm{M}$-B ratios are calculated as the ratio of the sum of the book value of assets (COMPUSTAT item 6), plus the market value of equity (price times number of shares outstanding, items 24 and 25, respectively), minus the sum of the book value of equity (item 60) and deferred taxes (item 74) divided by the book value of assets.
} 
that is significant at the five-percent level. This difference alone, however, cannot be interpreted as evidence that family heirs retard innovation.

\section{C. College Selectivity}

I compile available information on CEO academic histories using six sources: (1) the Dun \& Bradstreet Reference Book of Corporate Managements (various years), (2) Standard \& Poor's Register of Corporations, Directors, and Executives, (3) the Marquis Who's Who in Finance and Industry (various years), (4) Thomson Gale online Biography Resource Center, (5) the Dow Jones Inc. Factiva online library, and (6) web searches.

Based on Barron's (1980) rankings I sort CEOs into two groups: selective college (SC) if entering executives were reported to have attended a "very competitive" or more selective undergraduate institution (top 189 institutions), and less selective college (LSC), otherwise. ${ }^{16}$ CEOs with missing college information or those who attended foreign colleges are classified as LSC CEOs. While sensitivity of the results to the omission of these observations will be presented, I favored this classification since (1) CEOs are arguably more likely to disclose their alma mater and thus more likely to be documented in the databases described above when they attended prominent colleges, and (2) I am not aware of a comprehensive ranking of foreign undergraduate institutions relative to American colleges.

Using these categories I identify 141 SC CEOs (42 percent). 68 family heirs or 56 percent were classified as SC, while 73 or only 34 percent of unrelated CEOs were. This share of SC family heirs may be argued to be low since these CEOs represent the "elite” of family successors and because they are the offspring of wealthy individuals for whom education costs were unlikely to determine which college they attended. Furthermore, for a college to be included in the SC definition, it only needed to admit students who ranked among the top 50 percentile of their graduating high school class (Barron’s (1980)).

Using undergraduate as opposed to graduate educational records has several advantages. First, the college attended by incoming CEOs was identified in 90 percent of the cases. In contrast, I can only trace graduate studies for 39 percent of them. Second, there is no unified ranking of graduate programs of which I am aware that provides the relative standings of all

\footnotetext{
${ }^{16}$ The top three classifications in Barron's (1980) are "Most Competitive," "Highly Competitive," and "Very Competitive," which include 33, 52 and 104 undergraduate institutions, respectively. The sensitivity of differential performance to alternative definitions of college selectivity is further analyzed in Table 7.
} 
institutions across degrees and programs. Yet some inference could potentially be made out of those instances where incoming CEOs were reported as having pursued graduate studies. In Section V, I assess whether using graduate school information improves the sharpness of the test on differential CEO performance.

\section{Predictions}

According to the online Oxford English Dictionary, nepotism is "the showing of special favor or unfair preference to a relative in conferring a position, job, privilege, etc.” Under this definition, if nepotism were to be at work in the firms under analysis, we should expect that:

\section{(1) Family heirs should negatively affect performance on average.}

If a share of family CEO promotions were based on kinship rather than on merit, less competent family CEOs would not have been elected in a competitive contest. This lower tail in the distribution of family CEOs should, all other things being equal, be expected to be detrimental to firm performance. In contrast, merit-based successions of unrelated CEOs should imply that the lower tail of the distribution of unrelated CEOs is likely less pronounced. As a result, the average performance for the family heir group should be lower than the average performance of the unrelated CEO group, provided that CEO talent is material for firm performance.

(2) LSC family heirs should underperform relative to family heirs who attended selective undergraduate institutions.

In the absence of an exogenous source of variation in the selection of family and unrelated CEOs, I use information on the educational background of CEOs to test for evidence that kinship overrides competence in the promotion of family heirs. Specifically, if CEOs are competitively allocated, information on the quality of the undergraduate institutions they attended should not predict subsequent firm performance, since this information would likely be outweighed by all other relevant information related to their professional careers. If, however, 
CEOs are appointed from within the family without proper consideration to merit, then the type of college attended by family CEOs might be a valuable signal of their ability or motivation (Spence (1974)), particularly in the case of family heirs who, despite their family background and resources, failed to attend a selective undergraduate institution.

A caveat on testing for family-heir ability using the college attended by CEOs is that they are imperfect measures of ability, and in consequence, the estimated coefficients using these proxies for talent would tend to be biased towards zero.

\section{(3) College selectivity should not predict post-succession differences in performance} for unrelated CEOs.

LSC unrelated CEOs are promoted from a large pool of candidates who are required to show promise of their ability to run a corporation before being promoted to the top executive office. Thus, if they lack the merit for this post they should be discarded. As argued above, we would expect that the information on the quality of the undergraduate institutions attended by these CEOs to be overshadowed by their relevant post-graduation credentials.

Following the CEO turnover literature (Denis and Denis (1995); and Huson et al. (2004)), I now test for these hypotheses using an event-study methodology (Section IV) and subsequently, using within-firm analysis in performance based on measures of accounting operating performance and relative market valuation around CEO transitions (Section V).

\section{Event-Study on CEO Succession Decisions}

In this section, I examine announcement and long-term abnormal returns around CEO successions for family and unrelated transitions.

The advantage of market-based tests of performance is that we can potentially estimate the value of entering CEOs conditional on all relevant information (Warner, Ross L. Watts, and Karen H. Wruck (1988); Michael S. Weisbach (1988); and Denis and Denis (1995)). Thus if unrelated CEOs were expected to over (under) perform relative to family heirs, one should expect their firms to observe positive (negative) abnormal returns. 
This strategy has several shortcomings. First, the identity of incoming CEOs might be anticipated by the market. Over 80 percent of management changes yield an internal successor (Denis and Denis (1995), Huson et al. (2004), and this paper). Second, turnover decisions might by themselves reveal information related to firms' prospects, irrespective of CEO characteristics. Thus, even when, for example, incoming CEOs are superior to their predecessors, the net estimated abnormal return could be negative. Similarly, firms could strategically time the release of material information and tie it to CEO succession decisions in order to smooth stock prices.

In Table 3, I present average abnormal returns around CEO announcements for two-day and five-day event windows for all successions, and for two-day event windows when management changes were broken down by departing status of CEOs (retirements and unexpected deaths), by internal and external successions, and by college selectivity. ${ }^{17}$ Abnormal returns are calculated using the capital asset pricing model (CAPM) ${ }^{18}$

As Column I in Table 3 indicates, the bulk of successions in these firms with concentrated ownership and family executives were classified either as "retirements" (260 successions or 78 percent) or as internal (295 successions or 88 percent), which is consistent with previous studies (Morck et al. (1989); and Robert Parrino (1997)) that have documented that forced turnover is rare under these circumstances.

Column II in Table 3 shows that on average, family successions are associated with abnormal returns that are no different from zero at conventional levels. In contrast, Column III shows that for unrelated successions, the estimated excess returns are always positive and sometimes significantly different from zero. The estimated abnormal return for the latter group, where significant, was in the 0.94 to 4.8 percent range. Yet when I test for differences across groups I find that while on average such differences tend to be statistically significant, they are driven by a small number of observations: in all cases the Mann-Whitney test cannot reject that both distributions are the same at conventional levels. This interpretation is reinforced by rows

\footnotetext{
${ }^{17}$ Internal transitions are cases where the incoming CEO joined the firm at least a year prior to his or her promotion. Retirements are based on news reports, which are subject to the limitation that, as previous studies have indicated (Weisbach (1988)), companies do not announce the true reason behind CEOs' resignations. Sudden deaths are cases where the departing CEO was either a member of the founding family or a large shareholder who died in office due to an unexpected event.

${ }^{18}$ Abnormal returns are calculated based on the value weighted market-model using daily return data for a 200-day window $(-230,-30)$ before each announcement. Stock price data are from the Center for Research in Security Prices (CRSP). Abnormal returns were calculated using the Eventus program.
} 
four and five, which show that abnormal returns are only statistically different across groups if I include external unrelated CEOs.

The sixth row in Table 3 shows that, as reported by Johnson et al. (1985), a sudden death of a CEO who is a founder or a member of the founding family is associated with positive abnormal returns (6.6 percent). Ten of these 12 deaths are associated with a positive abnormal return. The small number of observations precludes finer analysis that could help disentangle changes in the probability of a corporate control contest (Johnson et al. (1985); Luigi Zingales (1995); and Slovin and Sushka (1993)) from the direct effect of the differential ability of new management teams.

Sorting by college selectivity I find that firms with SC CEOs do not seem to bring about significant abnormal returns upon the announcement of succession decisions. This is also the case for LSC heir firms. In contrast, firms that promote unrelated LSC CEOs observe positive abnormal returns. The average difference of 1.8 percentage points across LSC firms is significant at the 10-percent level and, as before, the Mann-Whitney test indicates that it is explained by a few observations.

An alternative way to assess the differential fate of investors around CEO transitions is to estimate long-term abnormal returns for firms in the sample. The advantage of long-term event analysis is that if the information on the relevant qualities of CEOs is revealed slowly in time, we could estimate its impact on performance even when two-day announcement effects are not significant. Yet this approach is subject to the same criticisms inherent to event-studies as discussed above. In particular, long-anticipated effects on performance (before the long-term window of analysis) would not be estimated and concurrent events that are unrelated to CEOs' talent but that affect firms’ prospects might be confounded in the estimated returns.

Following Huson et al. (2004), and Mark Mitchell and Erik Stafford (2000), I calculate monthly calendar-time portfolio returns resulting for portfolios that bought shares in firms subject to a CEO transition within the following 36 months, as well as for portfolios invested in firms that underwent a succession in the preceding 36 months. I estimate calendar-time portfolio returns using the CAPM and the four-factor market-model (see Fama and French (1993); and Jegadeesh and Titman (1993)). As a result, I report average abnormal returns using these two models and given that multifactor models do not completely describe returns (Fama and French 
(1993)), I also report adjusted abnormal returns, net of the average abnormal return of 1,000 random samples of otherwise similar portfolios of non-event firms. ${ }^{19}$

Results are presented in Table 4. Columns I through III show that before CEO transitions, the firms in the sample, regardless of their type, did not earn significant abnormal returns relative to any of the benchmarks presented. This finding is comparable to previous findings on voluntary transitions, which are the bulk of the successions in this paper. Interestingly, the portfolio of post-CEO transition firms achieves economically large and statistically significant abnormal returns. Panel A reports that the implied three-year estimated abnormal return for all firms in the sample ranges from 18.8 percent using the adjusted-four-factor model (Column VI) to 29.4 percent using the CAPM (Column IV), significant at the one-percent level.

Panel B in Table 4 reports post-succession abnormal returns for unrelated and family CEO firms. In support to the idea that unrelated transitions might be beneficial for investors, I find that portfolios of unrelated CEO firms earn substantial abnormal returns after transitions. Implicit three-year excess returns are in the 18 to 29 percent range depending on the benchmark specification. In contrast, abnormal returns for family CEO firms are not different from zero at conventional levels. Panel C shows that portfolios of family CEO firms formed using the college selectivity of incoming CEOs do not earn significant abnormal returns. In sum, estimated abnormal returns indicate that after CEO transitions, the portfolios of firms with the lowest and highest post-transition returns are family LSC CEO and unrelated CEO firms, respectively.

${ }^{19}$ In each month $t$, all firms subject to a CEO succession within the next (prior) 36 months are included in that month's pre (post) transition portfolio. Mean portfolio returns, $r p_{t}$ are used to estimate abnormal returns using the following regression:

$$
\left(r p_{t}-r f_{t}\right)=\alpha+\beta_{1}\left(r m_{t}-r f_{t}\right)+\beta_{2} S M B_{t}+\beta_{3} H M L_{t}+\beta_{4} U M D_{t}+\varepsilon_{t}
$$

where $r f_{t}$ is the risk-free rate calculated using one-month Treasury-bill rates. $\left(r m_{t}-r f_{t}\right)$ is the market risk premium, calculated as the difference between the value-weighted return on all NYSE, AMEX, and NASDAQ stocks from the CRSP less the risk-free rate. $S M B_{t}$ is the return difference between portfolios of small stocks and big stocks. $H M L_{t}$ is the return difference between portfolios of high book-to-market stocks and low book-to-market stocks. $U M D_{t}$ is the return difference between portfolios of high prior-return stocks and low prior-return stocks. $\alpha C A P M$ measures the monthly abnormal return when $S M B_{t}, H M L_{t}$, and $U M D_{t}$ are omitted. $\alpha$ four factor model is the intercept from the regression above. Adj. $\alpha$ is the difference between the estimated intercept and the average intercept from 1,000 random samples of otherwise similar non-event firms, and its test statistic is estimated as $t=\frac{\hat{\alpha}-E(\alpha)}{s e}$, where se is the standard error of the estimate from the sample firms. A minimum of five firms in the event portfolio is required. The implied three-year abnormal return is calculated as [ $\left.(1+\alpha)^{36}-1\right]$. Data on these factors were obtained from Ken French’s website: http://mba.tuck.dartmouth.edu/pages/faculty/ken.french. 
On the whole, the event-study results point to higher market valuations for firms that select unrelated CEOs and to insignificant results for family CEOs. As discussed above, these estimated effects should be interpreted with caution. An insignificant effect might alternatively mean (1) that a transition was expected and already incorporated into prices, (2) that the perceived impact of incoming CEOs is negligible or (3) that there were confounding effects that precluded a clean estimate of the true value of entering managers. Needless to say, criticisms (1) through (3) also apply for significant results. Consequently, this market-based approach cannot by itself establish the differential performance of incoming CEOs.

\section{Main Results}

An alternative strategy for testing the consequences of family relative to unrelated successions is to compare firm performance before and after each CEO transition for family and unrelated CEOs. Focusing on differences in performance allows us to control for time-invariant differences in firm characteristics that might influence performance. It also provides an intuitive null hypothesis: unless a drastic event occurs, we should expect negligible differences in performance around CEO successions.

The measures of performance used in this section are operating return on assets (OROA), net income to assets (ROA) and market-to-book ratios (M-B), as defined in Section II. The focus on cash flow-based measures of performance such as OROA follows the CEO turnover literature (Denis and Denis (1995); Huson et al. (2004)), while the use of relative valuation measures of performance follows the ownership concentration and family firm literatures (see for example Morck et al. (1988b); Anderson and Reeb (2003); and Villalonga and Amit (2006)).

OROA is a measure of current profitability, and arguably, the simplest measure of overall firm performance. ROA captures the return that shareholders receive relative to total assets, but it is potentially affected by changes in the capital structure of firms that might not reflect fundamental operational efficiency. Both operating and net income are potentially misleading as measures of firm performance in that they only capture present profitability. Recent corporate scandals show that these measures can be subject to drastic manipulation. To partially address these limitations, I use M-B ratios, a forward-looking measure of performance that serves as a proxy for Tobin's Q, namely, the market value of assets relative to their replacement costs. 
In order to prevent results from capturing time or differential industry trends, and to avoid the impact of mean-reversion from pre-transition performance, I emphasize results based on industry- and performance-adjusted variables. ${ }^{20}$

\section{V.A. Difference of Means}

To analyze the performance of family and unrelated CEOs, I start by presenting mean differences in firm performance before and after transitions. The first row in Table 5 reports the difference in the three-year average unadjusted OROA after CEO successions minus the threeyear average OROA before transitions. ${ }^{21}$ The average difference for the firms in the sample is 0.55 percentage points and is not statistically different from zero.

When firms are classified by incoming CEOs' family links, I find that firms that promote family CEOs undergo average declines in unadjusted OROA of 1.88 percentage points, significant at the one-percent level. In contrast, the difference in profitability of firms that appoint non-family CEOs is 0.21 percentage points, and is not different from zero at conventional levels. The resulting difference-in-differences is -2.09 percentage points, significant at the one-percent level. In economic terms, it indicates a gap in performance equal to 15 percent of the pre-transition unadjusted level of OROA.

A closer test of the nepotism hypothesis is to compare the performance of family CEOs when sorted by the colleges they attended. Under nepotism, family successors are more likely to be promoted to the CEO-post irrespective of merit. As a result, firms with family heirs who exhibit high motivation or talent might experience superior performance relative to those family firms in which the family CEO lacked them. Firms that promote unrelated CEOs, in contrast, are better placed to avoid this extreme lower tail in the performance distribution by promoting CEOs with a proven track record, and whose post-graduation professional experience before being appointed a CEO would likely outweigh the informational content of the college they attended.

The results are startling. Family CEOs who attended less selective colleges (LSC) account for the entire decline in performance observed by the group of firms that promote family CEOs. For them, OROA falls by 4.31 percentage points (27.7 percent decline relative to own

\footnotetext{
${ }^{20}$ Using unadjusted or industry-adjusted performance measures does not affect the key findings of this paper (results not shown).

${ }^{21}$ To prevent potential biases derived from earnings manipulations or taking "big baths," the year of succession is omitted. Including the year of succession does not affect the results of this paper.
} 
pre-transition levels), significant at the one-percent level. More revealing, 40 out of the 54 observations in this group of family LSC CEOs or 74 percent are negative. In contrast, firms that promote family CEOs who attended selective colleges (SC) do not exhibit significant differences in operating profitability around successions. The estimated difference-in-differences for firms with family LSC CEOs relative to family SC firms reported in Column VII is 4.36 percentage points, significant at the one-percent level.

I also report the estimated difference-in-differences of family LSC CEOs relative to two alternative control groups: the universe of unrelated CEOs and the sub-sample of unrelated CEOs who also attended less selective undergraduate institutions. In both cases, the estimated gap in performance is economically large and statistically significant, ranging from -4.52 percentage points relative to all unrelated CEOs to -4.89 percentage points relative to firms that promoted unrelated LSC CEOs. This latter difference shows that the differential in performance described above is not explained by inferior academic training per se, but rather is potentially indicative of the lower ability or motivation of family LSC CEOs.

Table 5 Panels B and C present industry-and industry-and-performance adjusted OROA, respectively. The difference-in-differences results indicate the relative patterns of performance between family and unrelated CEO firms, and in particular, between family LSC CEO and other firms are not explained by differential industry trends or mean-reversion in operating performance. Family CEOs significantly trail unrelated CEOs on average, and heir underperformance is explained by LSC family CEOs.

One concern with the difference-in-difference analysis is that firms in the sample might exhibit differential pre-transition trends. This problem is significantly reduced by matching firms with an industry- and performance-adjusted control group the year prior to CEO transitions (Panel C). Nevertheless, in order to test for significant differences in OROA across groupings, I examine differences in profitability by comparing profitability around years $t=-1$ and $t=-3$.

The second row in Table 5 Panel $\mathrm{C}$ documents that on average, all transition firms significantly underperform relative to their control groups by 1.2 percentage points. This result shows that sample firms while more profitable than their industry averages (Table 2), they exhibit a declining trend in the three years leading to succession. Broken by family ties, pretransition performance is -1.69 and -0.93 percentage points for family and non-family CEO firms, respectively. The difference in pre-transition performance across groups is, however, not 
statistically different from zero suggesting that pre-succession trends do not explain the subsequent differential gaps in performance reported above. Furthermore, there is no significant evidence that firms associated with LSC family CEOs performed significantly differently in comparison to those that appointed unrelated CEOs and that as a result, pre-transition profitability can explain post-succession gaps in performance.

The third row in Table 5 Panel $\mathrm{C}$ shows differences in industry-and performanceadjusted OROA between years $t=+3$ and $t=-1$ around CEO transitions. As before, family transitions on average are associated with relatively lower OROA. These gaps in performance are entirely explained by firms that promote LSC family CEOs, and the difference-in-differences in OROA between LSC-family-CEO firms and any other group is economically large and significant at the one-percent level, suggesting that LSC family heirs hurt firm performance.

In Panels D and E of Table 5, I reexamine the differential performance of family and unrelated CEOs, and in particular, of family LSC CEOs, using as alternative measures of performance industry- and performance-adjusted net income to assets and M-B ratios. M-B ratios are of particular interest since anticipated declines in profitability are likely to be incorporated into these ratios even before incoming CEOs take the helm. Net income analysis yields identical conclusions as those obtained using OROA. Interestingly, the observed gap in performance for LSC family CEO firms measured using market-to-book ratios is at least 0.26 (17 percent relative to its own pre-transition average M-B ratios) when compared to SC family CEOs. The implicit gap is even larger when compared to the observed changes in M-B ratios experienced by unrelated CEOs.

Differences in M-B ratios and net income to assets around CEO transitions reinforce the patterns of performance described using OROA and are, overall, consistent with nepotism, in that (1) firms that promoted family CEOs are associated with significantly lower gains in performance relative to firms that appointed unrelated CEOs; (2) LSC family CEO firms account for the economically and statistically large gaps in operating profitability and M-B valuations; and (3) the performance of LSC family CEO firms is significantly worse than the performance of SC family or unrelated SC or LSC CEOs firms.

A concern in interpreting these results is that SC- and LSC-family CEOs might differ in their age or labor experience at the time of succession, and that these variables by themselves might explain why LSC family CEOs underperform. In untabulated results, I find that the 
average age of LSC-family heirs at the time of promotion was 42.33 relative to 42.96 for SCfamily CEOs. The difference is not statistically different from zero. Similarly, the mean difference in the number of years of experience at the time of promotion is less than one year, which again is not statistically different from zero at conventional levels.

\section{V.B. Alternative Sub-Samples and Alternative Measures of College Selectivity}

Table 6 explores whether alternative categorizations of firms by several characteristics related to family ownership or family involvement in the board of directors, affect the abovedescribed differential patterns in performance. The table reports three-year mean differences in performance using industry- and performance-adjusted OROA. For reference, the first row in Table 6 shows the differences reported in the first row of Table 5 Panel C for all, unrelated and family successions, and for the sub-samples of LSC and SC family heirs.

The second row in Table 5 examines differences in performance for firms where family ownership was reported to be at least five percent of shares (265 cases), and the third row examines firms where at least two directors were related by blood or marriage (190 cases). Both groupings reinforce the results discussed above: (1) family heirs on average underperform

relative to non-family CEOs and (2) the weaker performance of firms that promote family CEOs is explained by LSC family heirs.

The fourth and fifth rows in Table 6 show that narrower definitions of family successions, such as looking solely at firms where CEOs receive control directly from their kin (as opposed to an unrelated predecessor), or at cases where CEOs succeed in a firm that bears their name, do not affect the abnormally weak performance by LSC family heirs.

Panel A in Table 7 shows the robustness of the findings when narrower college selectivity criteria based on Barron's (1980) classifications are used. I find no significant difference in performance for family heirs who were reported to have attended "most," "highly," or "very" competitive colleges. Neither is there significant differences in performance for CEOs whose undergraduate institution was a foreign college or was not reported by the media. In contrast, I find that (a) family-heir firms underperform when incoming CEOs were reported to have attended U.S. colleges outside the top three selectivity tiers, and (b) that unrelated-CEO- 
firms whose top executives attended comparable-ranked institutions do not experience declines in profitability. ${ }^{22}$

An alternative strategy for investigating whether the decline in performance associated with family CEO-firms reflects individual traits is to subdivide the firms based on whether the incoming CEO was reported as having attended a graduate program. In Table 7, Panel B, I split the 148 firms that promoted CEOs who attended U.S. colleges outside the top 189 (where significant differences exist) using this graduate school indicator variable. I find that the 54 incoming CEOs—both family and non-family—who pursued graduate studies were correlated with higher performance relative to the 94 cases where no graduate program was reported by 2.2 percentage points, significant at the 10-percent level. Analyzing by family links, having attended a graduate program is associated with a higher OROA for both family and unrelated CEOs, but the difference is not different from zero at conventional levels. The key variable of interest, namely, the differential performance of family relative to unrelated CEOs remains large and significant for both groupings.

I also test whether the differential performance for family and unrelated CEOs varies as a function of plausible proxies for the importance that CEOs can have on firms' prospects. Specifically, failing to have an adequate CEO is potentially more damaging in innovative or uncertain industries. To test this idea empirically, in Panel C of Table 7 I subdivide the 148 firms whose CEOs' colleges were outside the top three tiers in Barron's (1980) selectivity criteria, according to whether their firms reported having undertaken R\&D expenses the year prior to transition. I use this R\&D dummy as a proxy for the technical skills demanded of a CEO in order to adequately manage a corporation. Interestingly, firms that promote family (unrelated) LSC CEOs observe larger declines (increases) in performance if they had positive R\&D activities, relative to those without $R \& D$ expenses, yet the difference is not significant at conventional levels. As before, these further controls do not affect the key differences in performance for family and unrelated CEO firms.

The evidence above provides empirical support to the nepotism predictions advanced in Section III. I find that (1) family heirs underperform on average, (2) family CEO underperformance exists only when, despite their family background, they attended a less

\footnotetext{
${ }^{22}$ Using unadjusted, industry-adjusted OROA, or unadjusted, industry or industry- and performance-adjusted M-B or ROA ratios as alternative measures of firm performance yields identical conclusions. Results are not shown.
} 
selective college, and (3) in contrast to family heirs, unrelated CEOs who attended comparable lower-ranked institutions were not associated with declines in profitability. In short, nepotism is found to be detrimental to firms exactly where one should expect it to show: in the lower tail of the distribution of family heirs.

\section{V.C. Firm Characteristics and Alternative Succession Decisions}

A potential concern not addressed thus far is that documented differentials in performance might be correlated with pre-succession observable variables, such as firm profitability, size, and board ownership, among others, and that these variables by themselves might explain why certain family firms perform differentially. This would be the case if, as in Benjamin E. Hermalin and Michael S. Weisbach (1998), a departing CEO's power (and influence to name an offspring as CEO) is driven by perceived ability, with this power tending to be higher if the firm is over-performing relative to its industry peers. Similarly, small firms might find it harder than other firms to hire competent managers and firms with entrenched board members might be doomed to failure irrespective of who is their CEO. Previous studies have shown that firm performance, size, and board characteristics affect firms' hiring and firing decisions (Weisbach (1988); Morck et al. (1989); Denis and Denis (1995); Parrino (1997)), as well as the selection of internal relative to external candidates (Parrino (1997)).

Table 8 presents variables that might affect the probability of observing internal, family, and LSC family successions. ${ }^{23}$ I report the decision to appoint an internal CEO in Columns I through III as benchmarks, and to facilitate the comparison of the analysis relative to the preceding CEO turnover literature.

I find that larger firms in this sample do not appear to have been more likely to promote CEOs from within. Firms where family directors had a larger share of the seats on the board were more likely to promote CEOs internally. This is not surprising as all family CEOs were promoted internally. In contrast, board ownership did not seem to affect this decision.

Firm performance does seem to affect the probability of internal promotions. While industry-adjusted OROA or M-B do not significantly affect the decision to hire a CEO from within (Column I), an indicator variable equal to one for those firms with above-median industry-adjusted OROA (Columns II and III) in the year prior transition, indicates that superior

\footnotetext{
${ }^{23}$ Table 8 reports estimated changes in probabilities using a maximum-likelihood probit model.
} 
performance leads to a 10-percentage points increase in the probability of observing an internal CEO, significant at the one percent level. In contrast, positive pre-transition research and development spending (R\&D) does not affect internal promotion decisions (Column III).

Columns IV through VI of Table 8 show probit models for the decision to hire a family successor using similar specifications to those in Columns I through III. In contrast to internal successions, the decision to hire a family heir does not seem to be determined by pre-transition performance. Neither higher industry-adjusted OROA nor M-B ratios seem to predict family transitions. In line with Table 2, size does not seem to predict family successions. Further, not surprisingly, an above-median presence of family members on the board is strongly correlated with family CEOs. Board ownership as a fraction of the total shareholdings and R\&D intensity, which in univariate tests have, respectively, a positive and a negative correlation with family successions, fail to be significant once we control for the share of family members in the board. Yet when this family board variable is omitted both ownership and R\&D intensity are strongly correlated with the decision to appoint a family CEO as expected: positively for ownership concentration, and negatively for firms that had positive $R \& D$ expenses the year prior to transition (results are not shown).

Columns VII through IX in Table 8 show that conditional on observing a family succession, LSC heirs are more likely to be promoted in smaller firms and in corporations with less ownership concentration. Industry-adjusted OROA is positively correlated with whether LSC heirs receive control, though M-B ratios do not seem to predict this decision (Column VII). The fraction of family-board members does not seem to affect the decision to appoint a LSC family heir. Finally, family-LSC CEOs are significantly less likely to be promoted in firms with positive R\&D spending (Column IX).

Overall, Table 8 shows that (1) external CEOs are more common in underperforming firms; (2) family CEOs are promoted in firms where the fraction of family members in the board is higher; and (3) LSC family CEOs are selected in relatively smaller and more successful firms, in firms with fewer R\&D spending and in settings with lower board ownership concentration, relative to other family heir firms. Yet Table 8 documents that there does not seem to be a bias in terms of pre-transition size or performance of firms that promote family heirs (Columns IV-VI), which suggests that, on average, the two groups of firms were comparable, ex-ante. 


\section{V.D. Performance around Successions: Regression Analysis}

To address concerns relating to mean-reversion in performance, the analysis presented in Tables V through VII emphasized industry- and performance-adjusted measures of operating performance (e.g. OROA). I further test for the robustness of the results to the introduction of pre-transition firm controls such as industry-adjusted OROA, M-B ratios, size, and board ownership characteristics, as well as controls for the quality of firm governance (Paul Gompers, Joy Ishii and Andrew Metrick (2003).) In Table 9, I present these results, using as dependent variables the difference (after minus before) in the three-year industry-adjusted OROA (Columns I through V) and the corresponding difference for M-B ratios (Columns VI through X.)

Family-CEO firms experience an average gap in industry- and performance-adjusted OROA equal to 2.7 percentage points relative to unrelated CEOs, even after controlling for year dummies, M-B ratios, firm size, and ownership concentration. This difference in performance is significant at the one-percent level.

Other results show that firm size, industry-adjusted OROA or M-B ratios do not predict differential performance. Interestingly, neither board ownership nor family board control significantly affect changes in OROA. Finally, the three-year average industry-and performance adjusted OROA is negatively correlated with gains in OROA ex-post, an observation consistent with mean-reversion.

In Column II in Table 9 we extend the previous specification to the inclusion of the Gompers et al. (2003) governance index for the 115 firms with matching pre-transition data. Higher management power (higher indexes) does not seem to be associated with significantly lower firm performance. ${ }^{24}$ Reducing the number of observations does yield the family CEO effect insignificant, which is explained by the fact that only 13 LSC family CEOs (those that explain heir underperformance) were promoted to the chief executive position in those firms with matching governance data.

Column III of Table 9 presents results when I split the entire sample by college selectivity. As before, family CEO firms underperform only in the case of LSC family heirs. The estimated gap in OROA for family LSC firms is -3.7 percentage points, significant at the fivepercent level.

24 Data was obtained from http://finance.wharton.upenn.edu/ metrick/governance.xls. Table 9 only includes information for firms with reported governance information in the year or prior to the year of CEO transition. 
Columns IV and V of Table 9 extend the analysis further by examining if the 194 LSC CEOs, family and unrelated, performed differently if they pursued graduate studies or if they were promoted to the top position in firms with positive $R \& D$ spending. The analysis documents an insignificant effect of graduate studies and of the level of R\&D spending on OROA both for non-family and family LSC CEOs.

In Table 9 Columns VI to X I examine the robustness of the results using differences in industry- and performance-adjusted M-B ratios as the dependent variable. This analysis confirms the results that (a) family CEOs are associated with lower performance on average, and that (b) LSC family heirs drastically hurt performance. The average decline in M-B ratios for the family heir group (LSC family group) is 0.25 (0.46), significant at the one-percent level (Columns VI and VIII, respectively). Interestingly, Column VII obtains evidence of significant family CEO underperformance even for the reduced sample of firms with matching governance information.

In Column IX I show that firms with LSC CEOs who were reported as having attended graduated school had higher gains in M-B ratios. Considering graduate school records does not, however, affect the strong and negative average gap in performance of LSC family CEOs. The interaction of graduate studies and family LSC CEOs is negative and larger in absolute value than the graduate studies effect.

Finally, in Column X, I show that LSC firms with positive R\&D expenses prior to CEO transitions are associated with significant increases in $\mathrm{M}-\mathrm{B}$ ratios of 0.37 . This positive effect of R\&D expenses on M-B ratios is, however, overshadow by the effect of LSC family CEO firms.

\section{V.E. CEO Separation Conditions and Family Characteristics}

In addition to the above-described controls, CEO separation conditions, such as the type of succession or the age at which the departing CEO retires, may reveal information about the state of affairs of a corporation that is not captured by firm characteristics. I therefore assess if (1) retirements (relative to non-retirements), (2) early CEO departures (before age 65), (3) cases where the departing CEO remained as chairman, or (4) CEO ownership concentration affect the differential performance of family versus unrelated CEOs. In Table 10, I use indicator variables to examine whether "retirements," "early departures," or the fact that the departing CEO remains 
as chairman predicts differential performance. ${ }^{25}$ Columns I through III indicate that this is not the case. Lastly, Column IV shows that CEO ownership concentration at the time of succession does not seem to be correlated with future performance gains.

Conditional on observing family successions, I also test whether alternative family characteristics, such as (1) entrants who are classified as family due to marriage but not to blood, (2) women CEOs, or (3) later generations relative to the founder, perform differentially. Table 11 reports the differential performance of “in-laws” (seven cases), who presumably face a higher bar in becoming CEOs relative to other family members. Column I indicates that the impact of in-laws while positive it is insignificant at conventional levels. Using similar logic, I examine whether women-family CEOs (four observations) perform differentially. In this latter case, the sign of the estimated coefficient is also positive and insignificant.

Column III examines the empirical support for the notion that the "third" (or later) generations tend to be particularly poor at running firms. The data does show that third (or later) generations (39 observations) experience average declines in OROA of 2.2 percentage points below the average performance of firms that pass control to the second generation (significant at the 6-percent level). This latter result might be interpreted as at least partially consistent with the popular adage "shirtsleeves to shirtsleeves in three generations." Lastly, Column IV shows that CEOs who share the firms' names do not tend to perform differently from other family CEOs (38 cases). That is, despite their argued non-monetary stake in the firm from having their names associated with the firms' products or invoices, there is no evidence of superior performance attached to them.

\section{Alternative Hypotheses and Performance Measures}

The preceding sections document that firms that promote family CEOs, and in particular those that name LSC family executives, observe large declines in performance. I have posited that these patterns of firm performance are consistent with nepotism. In this section, I explore alternative hypotheses that could account for the evidence thus far presented.

\footnotetext{
${ }^{25}$ All specifications in Tables 10 and 11 include the following additional controls (estimated coefficients not shown): ln sales, at year $\mathrm{t}=-1$, industry-adjusted OROA and M-B at year $\mathrm{t}=-1$, board ownership, family directors dummy, and mean three-year pre-transition industry- and performance adjusted OROA.
} 


\section{A. Implicit Contracts}

The relative gap in performance between family and unrelated CEOs may be explained by wrecked implicit contracts (Andrei Shleifer and Lawrence H. Summers (1988)). Unrelated managers or SC family heirs may favor transferring resources from other stakeholders, such as workers or local associations, to investors while LSC-family heirs may find it hard to renege on pre-existing implicit arrangements.

In Table 12, I test this hypothesis by examining differences in (1) the ratio of employment to assets (Column I), and (2) the ratio of sales of property, plant- and equipment to assets (Column II) around CEO successions. In Panel A, I present data for all successions and in Panel B, for family transitions only. To assess the differences in these dependent variables after transitions, I use an indicator variable after which takes the value of one in the post-succession period, an indicator variable for family (LSC-family heirs) and also use an interaction of the after dummy with the family (LSC-family) indicator variable. Columns I and II reject the idea that unrelated or SC-family firms tend to differentially fire workers or sell assets.

\section{B. Long-Term Perspective}

A second alternative hypothesis is that family executives take a long-term perspective on business decisions (Cadbury (2000)). According to this argument, family members will make the right business decision regardless of its consequences for current performance, and as a result, OROA might be lower today (though it is not clear why M-B should fall). I test for this hypothesis using firms' spending on R\&D. According to the differential horizon view, unrelated CEOs might be reluctant to increase R\&D spending since it hurts operating income (and earnings) today in return for uncertain payoffs that occur in the future, while family CEOs might engage in aggressive $R \& D$ projects that are costly to profitability today.

Column III of Table 12 shows that, as it was found in Table 2, family heirs tend to be promoted in firms with significantly lower R\&D spending, yet they do not seem to engage in statistically significant differential increases in R\&D activity upon succession. Panel B further shows that R\&D spending alone cannot explain why LSC family heir firms undergo drastic declines in performance. 


\section{VI.C. Overhead, Cost of Goods Sold, and Sales Growth}

In the last three Columns of Table 12, I test for differences in (1) the ratio of selling, general, and administrative expenses (SG\&A) net of R\&D to sales; (2) the ratio of cost of goods sold (COGS) to sales; and (3) sales growth. The first measure tries to capture changes in the level of salaries or other perquisites, while the second and third variables seek to assess if declines in performance can be traced to deteriorating supervision of operations or declining revenue growth.

While Panel A shows some evidence that family heirs as a group increase overhead (marginally significant) or are associated with significantly higher COGS (at the five-percent level), Panel B shows strong evidence that LSC (but not SC) family heirs are associated with significantly higher COGS. Firms that promoted LSC family heirs undergo differential increases in the ratio of COGS of three percentage points, a four percent increase relative to pre-transition levels. Finally, Panel B in Column VI shows that LSC family firms exhibit lower sales growth after CEO transitions. Relative to other family CEO firms, sales growth in LSC family firms falls by seven percentage points, a decline that is significant at the five-percent level.

In sum, this paper has documented that firms that promote family CEOs significantly underperform after successions relative to other firms that hire unrelated CEOs. The gap in performance of family CEO firms is observed using accounting profitability measures such as operating or net income to assets. Market valuation measures of performance such as M-B ratios or stock returns around CEO transitions also point to the superiority of non-family CEO successors. These latter measures indicate that the gains from appointing a CEO from a competitive pool of managers are substantial suggesting that the private benefits derived from naming a family-CEO are large.

I have stressed that the average differential performance of family CEO firms is explained by the large underperformance of family firms that appoint CEOs who attend less selective colleges. I have also shown that this latter group undergoes declines in profitability and exhibits lower market valuations that could be partially traced to higher costs of goods sold, and lower sales growth, which do not occur in other firms. I interpret the evidence as supportive of the idea that nepotism is prevalent in some CEO successions in U.S. publicly traded firms, and that appointing successors without giving adequate consideration to merit is costly to firm performance. 


\section{Conclusion}

This paper provides strong evidence that promoting family CEOs in publicly traded corporations significantly hurts performance even after controlling for firm and industry characteristics, and aggregate trends.

I find that, consistent with wasteful nepotism, declines in performance are prominent in firms that appoint family CEOs who did not attend a selective undergraduate institution. In contrast, comparable firms that promote non-family CEOs do not experience negative changes in performance, even when incoming unrelated CEOs did not attend selective colleges.

In 1891 Andrew Carnegie wrote: ${ }^{26}$ "The parent who leaves his son enormous wealth generally deadens the talents and synergies of the son." I cannot, however, explain if family CEOs who attend less prominent colleges hurt performance due to lower effort as Carnegie would suggest, or if weaker performance is the result of the relatively lower ability of heirs, which would tend to regress to the mean of the population (Galton (1886)). A natural extension of this paper would be to explore the consequences of family transitions in countries with poor financial development where concentrated ownership is more pervasive than in the United States (La Porta et al. (1999)) and where firm control is often inherited within the family ranks.

The implications of these results may have consequences outside corporate settings. My findings illustrate the virtues of contested relative to uncontested elections. World history has shown that selecting a skilled leader for a nation is complicated. However, finding a competent heir among the offspring of a retiring head is often disastrous.

\footnotetext{
${ }^{26}$ Cited by Holtz-Eakin et al. (1993), page 413.
} 


\section{REFERENCES}

Anderson, Ronald C. and Reeb, David M. "Founding-Family Ownership and Firm Performance: Evidence from the S\&P 500.” Journal of Finance, 2003, 58 (3), pp. 1301-28.

Aronoff, Craig E., Astrachan, Joseph H. and Ward, John L. Family Business Sourcebook II, Marietta, GA: Business Owner Resources, 1996.

Barber, Brad M. and Lyon, John D. "Detecting Abnormal Operating Performance: The Empirical Power and Specification of Test Statistics.” Journal of Financial Economics, 1996, 41 (3), pp. 35999.

Barclay, Michael J. and Holderness, Clifford G. "Private Benefits from Control of Public Corporations.” Journal of Financial Economics, 1989, 25 (2), pp. 371-95.

Barnes, Louis B. and Hershon, Simon A. "Transferring Power in the Family Business." Harvard Business Review, 1976, 54 (4) pp. 105-14.

Barron's Educational Series, Inc. Barron's Profiles of American Colleges. Great Neck, N.Y: 1980.

Becker, Gary S. and Tomes, Nigel. "Human Capital and the Rise and Fall of Families." Journal of Labor Economics, 1986, 4 (3 Part 2), pp. S1-39.

Berle, Adolf and Means, Gardiner. The Modern Corporation and Private Property. New York: McMillan, 1932.

Bhattacharya, Utpal and Ravikumar, B. "From Cronies to Professionals: The Evolution of Family Firms.” In Klein E., ed., Capital Formation, Governance and Banking. Hauppauge: Nova Science Publishers, 2005.

Burkart, Mike, Panunzi, Fausto, and Shleifer, Andrei. “Family Firms.” Journal of Finance, 2003, 58 (5), pp. 2167-2202.

Cadbury, Adrian. Family Firms and their Governance: Creating Tomorrow's Company from Today's. London: Egon Zehnder International, 2000.

Christensen, Christopher R. Management Succession in Small and Growing Enterprises. Boston: Graduate School of Business Administration, Harvard University, 1953.

Claessens, Stijn, Djankov, Simeon, and Lang, Larry H. P. "The Separation of Ownership and Control in East Asian Corporations.” Journal of Financial Economics, 2000, 58(1-2), pp. 81-112.

Davis James H., Schoorman, F. David, and Donaldson, Lex. "Toward a Stewardship Theory of Management.” 1997, Academy of Management Review, 22 (1), pp. 20-47.

Demsetz, Harold and Lehn, Kenneth. "The Structure of Corporate Ownership: Causes and Consequences,” Journal of Political Economy, 1985, 93 (6), pp. 1155-77.

Denis, David J. and Denis, Diane K. "Performance Changes Following Top Management Dismissals." Journal of Finance, 1995, 50 (4), pp. 1029-57.

Donnelley, Robert G. “The Family Business.” Harvard Business Review, 1964, 42 (4), pp.93-105.

Dow Jones Reuters Business Interactive LLC. Factiva. New York: 2002 to date.

Dun \& Bradstreet, Inc. Dun \& Bradstreet Reference Book of Corporate Managements. New York: various years.

Economist (The). “What's Gone Wrong for America's Right; The Republican Crisis.” London: Economist Newsletter, October 2005, 377 (8446), pp 12.

Faccio, Mara and Lang, Larry H. P. “The Ultimate Ownership of Western European Corporations.” Journal of Financial Economics, 2002, 65 (3), pp. 365-95.

Fama, Eugene F. "Agency Problems and the Theory of the Firm," Journal of Political Economy, 88 (2), 1980, pp. 288-307.

Fama, Eugene F. and French, Kenneth R. "Common Risk Factors in the Returns on Stocks and Bonds.” Journal of Financial Economics, 1993, 33 (1), pp.3-56.

Fama, Eugene F. and Jensen, Michael C. "Separation of Ownership and Control." Journal of Law and Economics, 1983, 26, pp. 301-25. 
Galton, Francis. “Family Likeness in Stature.” Proceedings of Royal Society, 1886, 40, pp. 42-72.

Gompers, Paul, Ishii, Joy, and Metrick, Andrew. "Corporate Governance and Equity Prices." Quarterly Journal of Economics, 2003, 118 (1), pp. 107-55.

Hermalin, Benjamin E. and Weisbach, Michael S. "Endogenously Chosen Boards of Directors and Their Monitoring of the CEO.” American Economic Review, 1998, 88 (1), pp. 96-118.

Holtz-Eakin, Douglas, Joulfaian, David, and Rosen, Harvey S. "The Carnegie Conjecture: Some Empirical Evidence.” Quarterly Journal of Economics, 1993, 108 (2), pp. 413-35.

Huson, Mark R., Malatesta, Paul and Parrino, Robert. "Managerial Succession and Firm Performance.” Journal of Financial Economics, 2004, 74 (2), 237-75.

Huson Mark R., Parrino, Robert, and Starks, Laura. "Internal Monitoring Mechanisms and CEO Turnover: A Long-Term Perspective.” Journal of Finance, 2001, 56 (6), pp. 2,265-97.

Jegadeesh, Narasimhan and Titman, Sheridian. "Returns to Buying Winners and Selling Losers: Implications for Stock Market Efficiency.” Journal of Finance, 1993, 48 (1), pp. 65-91.

Jensen, Michael C. and Meckling, William H. "Theory of the Firm: Managerial Behavior, Agency Costs, and Ownership Structure.” Journal of Financial Economics, 1976, 3 (4), pp. 305-60.

Johnson, W. Bruce, Magee, Robert P., Nagarajan, Nandu J., and Newman, Harry A. "An Analysis of the Stock Price Reaction to Executive Deaths: Implications for the Managerial Labor Market." Journal of Accounting and Economics, 1985, 7 (1-3), pp. 151-74.

Johnston, David C. "Dozens of Rich Americans Join in Fight to Retain the Estate Tax." New York Times, New York: February 14, 2001, pp. C.1.

Kandel, Eugene and Lazear, Edward P. "Peer Pressure and Partnerships." Journal of Political Economy, 1992, 100 (4), pp. 801-17.

Kepner, Elaine. “The Family and the Firm: A Coevolutionary Perspective.” Organizational Dynamics, 1983, 12 (1), pp. 57-70.

La Porta, Rafael, Lopez-de-Silanes, Florencio, and Shleifer, Andrei. "Corporate Ownership around the World.” Journal of Finance, 1999, 54 (2), pp. 471-517.

Lansberg, Ivan S. "Managing Human Resources in Family Firms: The Problem of Institutional Overlap.” Organizational Dynamics, 1983, 12 (1), pp. 39-46.

. "The Succession Conspiracy: Understanding Resistances to Succession Planning in First Generation Family Firms.” Family Business Review, 1988, pp. 119-43.

Levinson, Harry. "Conflicts that Plague Family Businesses.” Harvard Business Review, 1971, 49 (2) pp. 90-98.

Marquis Who's Who, Inc. Who's Who in Finance and Business. Chicago: various years.

McConaughy, Daniel L., Walker, Michael C., Henderson, Glenn V. Jr., and Mishra Chandra S. "Founding Family Controlled Firms: Efficiency and Value.” Review of Financial Economics, 1998, 7, pp. 1-19.

Mitchell, Mark, and Stafford, Erik. "Managerial Decisions and Long-term Stock Price Performance”, Journal of Business, 2000, 73, pp. 287-329.

Morck, Randall, Shleifer, Andrei, and Vishny, Robert W. "Characteristics of Hostile and Friendly Takeover Targets.” In Alan J. Auerbach, ed., Corporate Takeovers: Causes and Consequences. Chicago: National Bureau of Economic Research and The University of Chicago Press, 1988a, pp. 101-29.

. "Management Ownership and Market Valuation: An Empirical Analysis.” Journal of Financial Economics, 1988b, 20, pp. 293-315.

“Alternative Mechanisms for Corporate Control.”American Economic Review, 1989, 79

(4), pp. 842-52. 
Morck, Randall K., Stangeland, David A., and Yeung, Bernard. "Inherited Wealth, Corporate Control and Economic Growth: the Canadian Disease?” In Morck, Randall K. ed. Concentrated Corporate Ownership. Chicago: University of Chicago Press, 2000, pp. 319-69.

Mulligan, Casey B. “Galton Versus the Human Capital Approach to Inheritance.” Journal of Political Economy, 1999, 107 (6), pp. S184-224.

OED Online. Oxford University Press, September 2003, s.v. "Nepotism.”

Paine, Thomas. “Common Sense.” New York, NY: Bantam Dell, 2004, originally printed in 1776.

Parrino, Robert. "CEO Turnover and Outside Succession: A Cross-sectional Analysis.” Journal of Financial Economics, 1997, 46 (2), pp. 165-97.

Shleifer, Andrei, and Summers, Lawrence H. "Breach of Trust in Hostile Takeovers." In Alan J. Auerbach, ed., Corporate Takeovers: Causes and Consequences. Chicago: National Bureau of Economic Research and The University of Chicago Press, 1988, pp. 33-56.

Shleifer, Andrei, and Vishny, Robert W. "Large Shareholders and Corporate Control." Journal of Political Economy, 1986, 94 (3), pp. 461-88.

Slovin, Myron B., and Sushka, Marie E. "Ownership Concentration, Corporate Control Activity, and Firm Value: Evidence from the Death of Inside Blockholders.” Journal of Finance, 1993, 48 (4), pp. 1293-1321.

Smith, Brian F. and Amoako-Adu, Ben. "Management Succession and Financial Performance of Family Controlled Firms.” Journal of Corporate Finance, 1999, 5 (4), pp. 341-68.

Spence, Michael A. Market Signaling: Informational Transfer in Hiring and Related Processes. Cambridge: Harvard University Press, 1974.

Standard \& Poor's Corporation. Standard \& Poor's Register of Corporations, Directors and Executives. New York: various years.

Stein, Nicholas. “Son of a Chicken Man.” Fortune, May 2002. 145 (10), New York, NY, Time Inc., pp 206.

Stryker, Perrin. “Would You Hire Your Son?” Fortune, March 13, 1957. New York, NY, Time Inc. pp 122.

Thompson, Mark; Tumulty, Karen and Allen, Mike. "How Many More Mike Browns Are Out There?” Time, U.S. Edition. October 3, 2005, 166 (14), pp. 49.

Thomson, Gale. Biography Resource Center. Farmington Hills, MI: Gale Group.

Villalonga, Belén and Amit, Raphael. "How Do Family Ownership, Control, and Management Affect Firm Value?” Journal of Financial Economics, 2006, 80, pp. 385-417.

Warner, Jerold B., Watts, Ross L., and Wruck, Karen H. "Stock Prices and Top Management Changes.” Journal of Financial Economics, 1988, 20, pp. 461-92.

Weisbach, Michael S. “Outside Directors and CEO Turnover.” Journal of Financial Economics, 1988, 20, pp. 431-460.

Yermack, David. "Higher Market Valuation of Companies with a Small Board of Directors.” Journal of Financial Economics, 1996, 40 (2), pp. 185-211.

Zingales, Luigi. "What Determines the Value of Corporate Votes?” Quarterly Journal of Economics, 1995, 110 (4), pp. 1047-73. 
TABLE 1. INDUSTRY DISTRIBUTION OF CEO SUCCESSIONS BY FAMILY TIES

\begin{tabular}{|c|c|c|c|c|}
\hline Industry & $\begin{array}{c}\text { All } \\
\text { Successions }\end{array}$ & $\begin{array}{c}\text { Family } \\
\text { Successions }\end{array}$ & $\begin{array}{l}\text { Unrelated } \\
\text { Successions }\end{array}$ & $\begin{array}{c}\text { Industry's Share } \\
\text { in COMPUSTAT } \\
\text { firms in } 1994\end{array}$ \\
\hline & (I) & (II) & (III) & (IV) \\
\hline 1 Consumer Non-Durables & $\begin{array}{c}36 \\
(10.7)\end{array}$ & $\begin{array}{l}11 \\
(3.3) \\
{[30.6]}\end{array}$ & $\begin{array}{c}25 \\
(7.5) \\
{[69.4]}\end{array}$ & $\begin{array}{l}350 \\
(7.5)\end{array}$ \\
\hline 2 Consumer Durables & $\begin{array}{c}18 \\
(5.4)\end{array}$ & $\begin{array}{c}7 \\
(2.1) \\
{[38.9]}\end{array}$ & $\begin{array}{c}11 \\
(3.3) \\
{[61.1]}\end{array}$ & $\begin{array}{l}164 \\
(3.5)\end{array}$ \\
\hline 3 Manufacturing & $\begin{array}{c}79 \\
(23.6)\end{array}$ & $\begin{array}{c}28 \\
(8.4) \\
{[35.4]}\end{array}$ & $\begin{array}{c}51 \\
(15.2) \\
{[64.6]}\end{array}$ & $\begin{array}{c}720 \\
(15.4)\end{array}$ \\
\hline 4 Oil, Gas and Coal Extraction & $\begin{array}{c}12 \\
(3.6)\end{array}$ & $\begin{array}{c}4 \\
(1.2) \\
{[33.3]}\end{array}$ & $\begin{array}{c}8 \\
(2.4) \\
{[66.7]}\end{array}$ & $\begin{array}{l}217 \\
(4.7)\end{array}$ \\
\hline 5 Chemical and Allied Products & $\begin{array}{c}14 \\
(4.2)\end{array}$ & $\begin{array}{c}5 \\
(1.5) \\
{[35.7]}\end{array}$ & $\begin{array}{c}9 \\
(2.7) \\
{[64.3]}\end{array}$ & $\begin{array}{l}143 \\
(3.1)\end{array}$ \\
\hline 6 Business Equipment & $\begin{array}{c}54 \\
(16.1)\end{array}$ & $\begin{array}{l}19 \\
(5.7) \\
{[35.2]}\end{array}$ & $\begin{array}{c}35 \\
(10.4) \\
{[64.8]}\end{array}$ & $\begin{array}{c}939 \\
(20.1)\end{array}$ \\
\hline 7 Telephone and Television & $\begin{array}{c}6 \\
(1.8)\end{array}$ & $\begin{array}{c}1 \\
(0.3) \\
{[16.7]}\end{array}$ & $\begin{array}{c}5 \\
(1.5) \\
{[83.3]}\end{array}$ & $\begin{array}{l}158 \\
(3.4)\end{array}$ \\
\hline 9 Wholesale, Retail and Some Services & $\begin{array}{c}52 \\
(15.5)\end{array}$ & $\begin{array}{l}18 \\
(5.4) \\
{[34.6]}\end{array}$ & $\begin{array}{c}34 \\
(10.1) \\
{[65.4]}\end{array}$ & $\begin{array}{c}682 \\
(14.6)\end{array}$ \\
\hline 10 Healthcare, Medical Equipment and Drugs & $\begin{array}{c}13 \\
(3.9)\end{array}$ & $\begin{array}{c}8 \\
(2.4) \\
{[61.5]}\end{array}$ & $\begin{array}{c}5 \\
(1.5) \\
{[38.5]}\end{array}$ & $\begin{array}{c}555 \\
(11.9)\end{array}$ \\
\hline 12 Other & $\begin{array}{c}51 \\
(15.2)\end{array}$ & $\begin{array}{l}21 \\
(6.3) \\
{[41.2]}\end{array}$ & $\begin{array}{c}30 \\
(9.0) \\
{[58.8]}\end{array}$ & $\begin{array}{c}740 \\
(15.9)\end{array}$ \\
\hline Total & $\begin{array}{c}335 \\
(100.0)\end{array}$ & $\begin{array}{c}122 \\
(36.4)\end{array}$ & $\begin{array}{c}213 \\
(63.6)\end{array}$ & $\begin{array}{l}4,668 \\
(100)\end{array}$ \\
\hline
\end{tabular}

a. CEO successions are classified by family ties: family when the incoming CEO was related by blood or marriage to the departing CEO, to the founder, or to a large shareholder of the corporation (Column II); unrelated, otherwise (Column III).

b. Firms are sorted by industry using Fama-French's 12-industry definitions, excluding those in industries eight (utilities) and eleven (finance): http://mba.tuck.dartmouth.edu/pages/faculty/ken.french.

c. The number of U.S. firms in each of these industry categories in 1994 in the COMPUSTAT database is reported in Column IV. The share of successions as a percentage of the total number of events in the sample (Columns I-III) or as a percentage of all firms in the COMPUSTAT database (Column IV) is reported in parentheses. The share of successions as a percentage of the total number of successions per industry is reported in square brackets. 


\begin{tabular}{|c|c|c|c|c|}
\hline \multirow[b]{2}{*}{ Variable } & \multirow[b]{2}{*}{ All } & \multicolumn{2}{|c|}{ Type of Succession } & \multirow[b]{2}{*}{$\begin{array}{c}\text { Difference } \\
\text { of Means }\end{array}$} \\
\hline & & Family & Unrelated & \\
\hline & (I) & (II) & (III) & (IV) \\
\hline Number of CEO transitions & 335 & 122 & 213 & \\
\hline Age promoted (years) & $\begin{array}{r}47.863 \\
(0.4065)\end{array}$ & $\begin{array}{r}42.680 \\
(0.5693)\end{array}$ & $\begin{array}{r}50.831 \\
(0.4351)\end{array}$ & $\begin{array}{r}-8.151 \\
(0.7162)\end{array}$ \\
\hline Ownership (ratio) & $\begin{array}{r}0.055 \\
(0.006)\end{array}$ & $\begin{array}{r}0.112 \\
(0.014)\end{array}$ & $\begin{array}{r}0.022 \\
(0.004)\end{array}$ & $\begin{array}{r}0.090 \\
(0.0149)\end{array}$ \\
\hline Board ownership (ratio) & $\begin{array}{r}0.265 \\
(0.0110)\end{array}$ & $\begin{array}{r}0.319 \\
(0.0198)\end{array}$ & $\begin{array}{r}0.234 \\
(0.0127)\end{array}$ & $\begin{array}{r}0.085 \\
(0.0235)\end{array}$ \\
\hline Firm assets (millions of 2002 dollars) & $\begin{array}{r}1,305.7 \\
(198.167)\end{array}$ & $\begin{array}{r}1,109.3 \\
(281.726)\end{array}$ & $\begin{array}{r}1,418.1 \\
(266.824)\end{array}$ & $\begin{array}{r}-308.8 \\
(387.915)\end{array}$ \\
\hline $\begin{array}{l}\text { Market value of equity (millions of } \\
2002 \text { dollars) }\end{array}$ & $\begin{array}{r}1,532.7 \\
(417.773)\end{array}$ & $\begin{array}{r}1,195.7 \\
(364.696)\end{array}$ & $\begin{array}{r}1,725.7 \\
(623.304)\end{array}$ & $\begin{array}{r}-530.0 \\
(722.296)\end{array}$ \\
\hline Operating return on assets $(O R O A)$ (ratio) & $\begin{array}{r}0.140 \\
(0.0050)\end{array}$ & $\begin{array}{r}0.141 \\
(0.0075)\end{array}$ & $\begin{array}{r}0.139 \\
(0.0066)\end{array}$ & $\begin{array}{r}0.002 \\
(0.0100)\end{array}$ \\
\hline Industry adjusted $O R O A$ (ratio) & $\begin{array}{r}0.032 \\
(0.0052)\end{array}$ & $\begin{array}{r}0.033 \\
(0.0076)\end{array}$ & $\begin{array}{r}0.031 \\
(0.0069)\end{array}$ & $\begin{array}{r}0.002 \\
(0.0103)\end{array}$ \\
\hline $\begin{array}{l}\text { Industry and performance adjusted } O R O A \\
\text { (ratio) }\end{array}$ & $\begin{array}{r}0.0004 \\
(0.0013)\end{array}$ & $\begin{array}{r}-0.0016 \\
(0.0016)\end{array}$ & $\begin{array}{r}0.0015 \\
(0.0018)\end{array}$ & $\begin{array}{r}-0.0030 \\
(0.0024)\end{array}$ \\
\hline $\begin{array}{l}\text { Net income to assets, industry and } \\
\text { performance adjusted (ratio) }\end{array}$ & $\begin{array}{r}0.0029 \\
(0.0017)\end{array}$ & $\begin{array}{r}0.0020 \\
(0.0025)\end{array}$ & $\begin{array}{r}0.0035 \\
(0.0022)\end{array}$ & $\begin{array}{r}-0.0015 \\
(0.0033)\end{array}$ \\
\hline Market-to-book ratio & $\begin{array}{r}1.484 \\
(0.0469)\end{array}$ & $\begin{array}{r}1.481 \\
(0.0955)\end{array}$ & $\begin{array}{r}1.485 \\
(0.0498)\end{array}$ & $\begin{array}{r}-0.004 \\
(0.1076)\end{array}$ \\
\hline R\&D spending to assets (ratio) & $\begin{array}{r}0.041 \\
(0.0040)\end{array}$ & $\begin{array}{r}0.029 \\
(0.0056)\end{array}$ & $\begin{array}{r}0.046 \\
(0.0051)\end{array}$ & $\begin{array}{r}-0.018 \\
(0.0076)\end{array}$ \\
\hline
\end{tabular}

a. CEO successions are classified by family ties: family when the incoming CEO was related by blood or marriage to the departing CEO, to a founder, or to a large shareholder of the corporation, and unrelated, otherwise.

b. Other variables are defined as follows. CEO age: the age at which the CEO is promoted. Ownership: the share of ownership held by the incoming CEO. Board ownership: the fraction of ownership held by officers and directors. Firm assets: the book value of total assets (2002 dollars, in millions). Market value of equity: the price per share multiplied by the number of shares outstanding (2002 dollars, in millions). Operating return on assets (OROA): the ratio of operating income to the book value of assets. Industry adjusted OROA: OROA less the median OROA of the relevant industry (two-digit SIC). Industry and performance adjusted OROA (net income): industry adjusted OROA (net income) minus the median of a control group of firms with similar performance. Performance controls are created by dividing COMPUSTAT firms into deciles sorted by the relevant variable in the year prior transition. The median of the relevant performance group of firms (ex-event) is then used as control. Market-to-book ratio: the ratio of the sum of the book value of assets plus the market value of equity minus the sum of the book value of equity and deferred taxes to the book value of assets. R\&D spending to assets: the ratio of spending on research and development (R\&D) to assets.

c. Ownership data are from proxy statements. CEO data are from proxy statements, news, and web searches. Firm data are from COMPUSTAT for the year prior to succession. Standard errors are reported in parentheses. 
TABle 3. Cumulative ABNORMAL RETURNS AROUND SUCCESSION ANNOUNCEMENTS

\begin{tabular}{|c|c|c|c|c|c|}
\hline \multirow[b]{2}{*}{ Firms and Event-Window } & \multirow[b]{2}{*}{ All } & \multicolumn{2}{|c|}{ Type of Succession } & \multirow[b]{2}{*}{ Difference } & \multirow[b]{2}{*}{$\begin{array}{l}\text { Mann Whitney } \\
|z| \text {-values }\end{array}$} \\
\hline & & Family & Unrelated & & \\
\hline & (I) & (II) & (III) & (IV) & (V) \\
\hline $\begin{array}{l}\text { All CEO successions } \\
\left(t_{0}, t_{+2}\right)\end{array}$ & $\begin{array}{r}0.0100 \\
(0.0044) \\
{[335]}\end{array}$ & $\begin{array}{r}-0.0018 \\
(0.0071) \\
{[122]}\end{array}$ & $\begin{array}{r}0.0167 \\
(0.0055) \\
{[213]}\end{array}$ & $\begin{array}{r}-0.0184 \\
(0.0089)\end{array}$ & 1.265 \\
\hline $\begin{array}{l}\text { All CEO successions } \\
\left(t_{0}, t_{+5}\right)\end{array}$ & $\begin{array}{r}0.0096 \\
(0.0047) \\
{[335]}\end{array}$ & $\begin{array}{r}-0.0016 \\
(0.0068) \\
{[122]}\end{array}$ & $\begin{array}{r}0.0160 \\
(0.0063) \\
\quad[213]\end{array}$ & $\begin{array}{r}-0.0176 \\
(0.0093)\end{array}$ & 1.585 \\
\hline $\begin{array}{l}\text { Successions reported as } \\
\text { "retirements" }\left(t_{0}, t_{+2}\right)\end{array}$ & $\begin{array}{r}0.0096 \\
(0.0049) \\
{[260]}\end{array}$ & $\begin{array}{r}-0.0020 \\
(0.0083) \\
{[97]}\end{array}$ & $\begin{array}{r}0.0165 \\
(0.0060) \\
{[163]}\end{array}$ & $\begin{array}{r}-0.0185 \\
(0.0103)\end{array}$ & 1.121 \\
\hline $\begin{array}{l}\text { Internal successions } \\
\left(t_{0}, t_{+2}\right)\end{array}$ & $\begin{array}{r}0.0048 \\
(0.0042) \\
{[295]}\end{array}$ & $\begin{array}{r}-0.0018 \\
(0.0071) \\
{[122]}\end{array}$ & $\begin{array}{r}0.0094 \\
(0.0052) \\
{[173]}\end{array}$ & $\begin{array}{r}-0.0111 \\
(0.0088)\end{array}$ & 0.746 \\
\hline $\begin{array}{l}\text { External successions } \\
\left(t_{0}, t_{+2}\right)\end{array}$ & & & $\begin{array}{r}0.0483 \\
(0.0180) \\
{[40]}\end{array}$ & & \\
\hline $\begin{array}{l}\text { Sudden death of departing } \\
C E O\left(t_{0}, t_{+2}\right)\end{array}$ & $\begin{array}{r}0.0657 \\
(0.0364) \\
{[12]}\end{array}$ & $\begin{array}{r}0.0376 \\
(0.0187) \\
{[6]}\end{array}$ & $\begin{array}{r}0.0938 \\
(0.0718) \\
{[6]}\end{array}$ & & \\
\hline Number of positive observations & & [5] & [5] & & \\
\hline $\begin{array}{l}\text { Incoming CEO attended a } \\
\text { "selective college" }(S C)\left(t_{0}, t_{+2}\right)\end{array}$ & $\begin{array}{r}0.0066 \\
(0.0075) \\
{[141]}\end{array}$ & $\begin{array}{r}-0.0027 \\
(0.0114) \\
{[68]}\end{array}$ & $\begin{array}{r}0.0153 \\
(0.0099) \\
{[73]}\end{array}$ & $\begin{array}{r}-0.0180 \\
(0.0151)\end{array}$ & 0.767 \\
\hline $\begin{array}{l}\text { Incoming CEO attended a } \\
\text { "less selective college" }(L S C)\left(t_{0}, t_{+2}\right)\end{array}$ & $\begin{array}{r}0.0124 \\
(0.0052) \\
{[194]}\end{array}$ & $\begin{array}{r}-0.0006 \\
(0.0072) \\
{[54]}\end{array}$ & $\begin{array}{r}0.0174 \\
(0.0066) \\
{[140]}\end{array}$ & $\begin{array}{r}-0.0180 \\
(0.0097)\end{array}$ & 1.181 \\
\hline
\end{tabular}

a. CEO successions are classified by family ties: family when the incoming CEO was related by blood or marriage to the departing CEO, to a founder, or to a large shareholder of the corporation, and unrelated, otherwise.

b. Successions are classified as retirements (or not) based on news reports.

c. Successions are classified as internal when incoming CEOs were hired by the firm earlier than a year before succession (all family successions were internal), and external otherwise.

d. A CEO is classified as having attended a selective college (SC) when he or she was reported to have attended a "very competitive" undergraduate institution or better (a total of 189 colleges) using Barron's (1980) rankings, and less selective college, otherwise.

e. Abnormal returns are calculated using the capital asset pricing model (CAPM). Windows of analysis are relative to actual announcement dates (in days), where $t=0$ is the day of the announcement. Stock returns data are from CRSP. Robust standard errors are in parentheses and the numbers of successions is reported in square brackets. 
TABLE 4. LONG-RUN ABNORMAL STOCK RETURNS AROUND CEO TRANSITIONS

\begin{tabular}{|c|c|c|c|c|c|c|}
\hline & \multicolumn{3}{|c|}{ Before } & \multicolumn{3}{|c|}{ After } \\
\hline & $\alpha C A P M$ & $\begin{array}{l}\alpha \text { four factor } \\
\text { model }\end{array}$ & Adj. $\alpha$ & $\alpha C A P M$ & $\begin{array}{l}\alpha \text { four factor } \\
\text { model }\end{array}$ & Adj. $\alpha$ \\
\hline & (I) & (II) & (III) & (IV) & $(\mathrm{V})$ & (VI) \\
\hline A. All CEO transitions & $\begin{array}{c}-0.00136 \\
(0.0019)\end{array}$ & $\begin{array}{c}0.00001 \\
(0.0014)\end{array}$ & -0.00078 & $\begin{array}{c}0.00718 \\
(0.0022)\end{array}$ & $\begin{array}{c}0.00569 \\
(0.0017)\end{array}$ & 0.00479 \\
\hline Implied 3-year abnormal return (percent) & -4.78 & 0.04 & -2.77 & 29.38 & 22.66 & 18.77 \\
\hline \multicolumn{7}{|l|}{ B. By type of succession: } \\
\hline Unrelated & $\begin{array}{l}-0.00257 \\
(0.0021)\end{array}$ & $\begin{array}{c}-0.00096 \\
(0.0016)\end{array}$ & -0.00201 & $\begin{array}{c}0.00709 \\
(0.0023)\end{array}$ & $\begin{array}{c}0.00666 \\
(0.0020)\end{array}$ & 0.00468 \\
\hline Implied 3-year abnormal return (percent) & -8.85 & -3.40 & -6.99 & 28.96 & 26.99 & 18.30 \\
\hline Family & $\begin{array}{r}0.00062 \\
(0.0024)\end{array}$ & $\begin{array}{c}0.00193 \\
(0.0022)\end{array}$ & 0.00172 & $\begin{array}{c}0.00378 \\
(0.0028)\end{array}$ & $\begin{array}{c}0.00246 \\
(0.0025)\end{array}$ & 0.00289 \\
\hline Implied 3-year abnormal return (percent) & 2.26 & 7.19 & 6.38 & 14.55 & 9.25 & 10.95 \\
\hline \multicolumn{7}{|c|}{ C. Family successions only: by college selectivity } \\
\hline Family-SC & $\begin{array}{r}0.00080 \\
(0.0025)\end{array}$ & $\begin{array}{l}-0.00082 \\
(0.0024)\end{array}$ & -0.00233 & $\begin{array}{c}0.00380 \\
(0.0030)\end{array}$ & $\begin{array}{c}0.00301 \\
(0.0028)\end{array}$ & 0.00325 \\
\hline Implied 3-year abnormal return (percent) & 2.92 & -2.91 & -8.05 & 14.63 & 11.43 & 12.39 \\
\hline Family-LSC & $\begin{array}{c}0.00044 \\
(0.0038)\end{array}$ & $\begin{array}{c}0.00300 \\
(0.0037)\end{array}$ & 0.00429 & $\begin{array}{c}-0.00066 \\
(0.0034)\end{array}$ & $\begin{array}{l}-0.00150 \\
(0.0029)\end{array}$ & -0.00085 \\
\hline Implied 3-year abnormal return (percent) & 1.60 & 11.39 & 16.66 & -2.35 & -5.26 & -3.01 \\
\hline
\end{tabular}

a. Abnormal returns are estimated using calendar-time portfolio regressions. In each month $t$, all firms subject to a CEO succession within the next (prior) 36 months are included in that month's pre (post) transition portfolio. Mean portfolio returns, $r p_{t}$ are used to estimate abnormal returns using the following regression:

$$
\left(r p_{t}-r f_{t}\right)=\alpha+\beta_{1}\left(r m_{t}-r f_{t}\right)+\beta_{2} S M B_{t}+\beta_{3} H M L_{t}+\beta_{4} U M D_{t}+\varepsilon_{t}
$$

where $r f_{t}$ is the risk-free rate calculated using one-month Treasury-bill rates. $\left(r m_{t}-r f_{t}\right)$ is the market risk premium, calculated as the difference between the value-weighted return on all NYSE, AMEX, and NASDAQ stocks from the Center for Research in Security Prices (CRSP) less the risk-free rate. $S M B_{t}$ is the return difference between portfolios of small stocks and big stocks. $H M L_{t}$ is the return difference between portfolios of high book-to-market stocks and low book-tomarket stocks. $U M D_{t}$ is the return difference between portfolios of high prior-return stocks and low prior-return stocks. $\alpha$ $C A P M$ measures the monthly abnormal return when $S M B_{t}, H M L_{t}$, and $U M D_{t}$ are omitted. a four factor model is the intercept from the regression above.

b. Adj. $\alpha$ is the difference between the estimated intercept from the regression above and the average intercept from 1,000 random samples of otherwise similar non-event firms, and its test statistic is estimated as $t=\frac{\hat{\alpha}-E(\alpha)}{s e}$, where $s e$ is the standard error of the estimate from the sample firms. A minimum of five firms in the event portfolio is required. The implied three-year abnormal return is calculated as $\left[(1+\alpha)^{36}-1\right]$. 
TABle 5. Differential Performance AROUnd CEO Transitions

\begin{tabular}{|c|c|c|c|c|c|c|c|c|c|}
\hline \multirow[b]{2}{*}{ Years } & \multirow[b]{2}{*}{ All } & \multicolumn{2}{|c|}{ Type of Succession } & \multirow[b]{2}{*}{ Difference } & \multicolumn{2}{|c|}{ Family only by College Type } & \multicolumn{3}{|c|}{ Differences } \\
\hline & & Family & Unrelated & & LSC & SC & $\begin{array}{l}\text { SC vs LSC } \\
\text { Family }=1\end{array}$ & $\begin{array}{l}\text { Family LSC } \\
\text { vs. unrelated }\end{array}$ & $\begin{array}{l}\text { All LSC=1: family } \\
\text { vs. unrelated }\end{array}$ \\
\hline & (I) & (II) & (III) & (IV) & $(\mathrm{V})$ & $(\mathrm{VI})$ & (VII) & (VIII) & (IX) \\
\hline Number of CEO transitions & 335 & 122 & 213 & & 54 & 68 & & & \\
\hline \multicolumn{10}{|c|}{ A. Operating return on assets (OROA) } \\
\hline $\begin{array}{l}\text { (3-year average after)- } \\
\text { (3 year average before) }\end{array}$ & $\begin{array}{r}-0.0055 \\
(0.0039)\end{array}$ & $\begin{array}{l}-0.0188 \\
(0.0059)\end{array}$ & $\begin{array}{r}0.0021 \\
(0.0050)\end{array}$ & $\begin{array}{r}-0.0209 \\
(0.0077)\end{array}$ & $\begin{array}{r}-0.0431 \\
(0.0092)\end{array}$ & $\begin{array}{r}0.0005 \\
(0.0070)\end{array}$ & $\begin{array}{l}-0.0436 \\
(0.0115)\end{array}$ & $\begin{array}{r}-0.0452 \\
(0.0104)\end{array}$ & $\begin{array}{r}-0.0489 \\
(0.0110)\end{array}$ \\
\hline \multicolumn{10}{|l|}{ B. Industry adjusted $\mathrm{OROA}$} \\
\hline $\begin{array}{l}\text { (3-year average after)- } \\
\text { (3 year average before) }\end{array}$ & $\begin{array}{r}0.0022 \\
(0.0040)\end{array}$ & $\begin{array}{c}-0.0114 \\
(0.0063)\end{array}$ & $\begin{array}{r}0.0100 \\
(0.0051)\end{array}$ & $\begin{array}{r}-0.0213 \\
(0.0081)\end{array}$ & $\begin{array}{r}-0.0349 \\
(0.0099)\end{array}$ & $\begin{array}{r}0.0073 \\
(0.0075)\end{array}$ & $\begin{array}{r}-0.0422 \\
(0.0124)\end{array}$ & $\begin{array}{r}-0.0448 \\
(0.0111)\end{array}$ & $\begin{array}{r}-0.0460 \\
(0.0117)\end{array}$ \\
\hline \multicolumn{10}{|c|}{ C. Industry and performance adjusted $\mathrm{OROA}$} \\
\hline $\begin{array}{l}\text { (3-year average after)- } \\
\text { (3 year average before) }\end{array}$ & $\begin{array}{r}0.0071 \\
(0.0037)\end{array}$ & $\begin{array}{c}-0.0059 \\
(0.0056)\end{array}$ & $\begin{array}{r}0.0146 \\
(0.0049)\end{array}$ & $\begin{array}{r}-0.0205 \\
(0.0074)\end{array}$ & $\begin{array}{c}-0.0259 \\
(0.0092)\end{array}$ & $\begin{array}{r}0.0100 \\
(0.0064)\end{array}$ & $\begin{array}{r}-0.0359 \\
(0.0112)\end{array}$ & $\begin{array}{r}-0.0404 \\
(0.0103)\end{array}$ & $\begin{array}{r}-0.0429 \\
(0.0108)\end{array}$ \\
\hline$(t=-1)-(t=-3)$ & $\begin{array}{r}-0.0121 \\
(0.0041)\end{array}$ & $\begin{array}{l}-0.0169 \\
(0.0080)\end{array}$ & $\begin{array}{l}-0.0093 \\
(0.0046)\end{array}$ & $\begin{array}{r}-0.0076 \\
(0.0093)\end{array}$ & $\begin{array}{l}-0.0081 \\
(0.0153)\end{array}$ & $\begin{array}{r}-0.0239 \\
(0.0078)\end{array}$ & $\begin{array}{r}0.0158 \\
(0.0171)\end{array}$ & $\begin{array}{r}0.0012 \\
(0.0159)\end{array}$ & $\begin{array}{r}-0.0045 \\
(0.0161)\end{array}$ \\
\hline$(t=+3)-(t=-1)$ & $\begin{array}{r}0.0120 \\
(0.0052)\end{array}$ & $\begin{array}{l}-0.0003 \\
(0.0097)\end{array}$ & $\begin{array}{r}0.0191 \\
(0.0059)\end{array}$ & $\begin{array}{r}-0.0194 \\
(0.0113)\end{array}$ & $\begin{array}{l}-0.0343 \\
(0.0186)\end{array}$ & $\begin{array}{r}0.0261 \\
(0.0081)\end{array}$ & $\begin{array}{r}-0.0603 \\
(0.0203)\end{array}$ & $\begin{array}{r}-0.0533 \\
(0.0194)\end{array}$ & $\begin{array}{r}-0.0546 \\
(0.0198)\end{array}$ \\
\hline \multicolumn{10}{|c|}{ D. Industry and performance adjusted net income/assets } \\
\hline $\begin{array}{l}\text { (3-year average after)- } \\
\text { (3 year average before) }\end{array}$ & $\begin{array}{r}0.0053 \\
(0.0041)\end{array}$ & $\begin{array}{c}-0.0078 \\
(0.0067)\end{array}$ & $\begin{array}{r}0.0128 \\
(0.0051)\end{array}$ & $\begin{array}{r}-0.0205 \\
(0.0084)\end{array}$ & $\begin{array}{l}-0.0283 \\
(0.0132)\end{array}$ & $\begin{array}{r}0.0085 \\
(0.0052)\end{array}$ & $\begin{array}{r}-0.0368 \\
(0.0142)\end{array}$ & $\begin{array}{r}-0.0410 \\
(0.0141)\end{array}$ & $\begin{array}{r}-0.0412 \\
(0.0145)\end{array}$ \\
\hline$(t=+3)-(t=-1)$ & $\begin{array}{r}0.0051 \\
(0.0064)\end{array}$ & $\begin{array}{l}-0.0146 \\
(0.0139)\end{array}$ & $\begin{array}{r}0.0163 \\
(0.0061)\end{array}$ & $\begin{array}{r}-0.0309 \\
(0.0152)\end{array}$ & $\begin{array}{l}-0.0606 \\
(0.0292)\end{array}$ & $\begin{array}{r}0.0211 \\
(0.0078)\end{array}$ & $\begin{array}{r}-0.0817 \\
(0.0301)\end{array}$ & $\begin{array}{r}-0.0769 \\
(0.0296)\end{array}$ & $\begin{array}{r}-0.0733 \\
(0.0299)\end{array}$ \\
\hline \multicolumn{10}{|c|}{ E. Industry and performance adjusted market to book ratio } \\
\hline $\begin{array}{l}\text { (3-year average after)- } \\
\text { (3 year average before) }\end{array}$ & $\begin{array}{r}0.1638 \\
(0.0394)\end{array}$ & $\begin{array}{r}0.0135 \\
(0.0577)\end{array}$ & $\begin{array}{r}0.2500 \\
(0.0516)\end{array}$ & $\begin{array}{r}-0.2365 \\
(0.0774)\end{array}$ & $\begin{array}{r}-0.1334 \\
(0.0902)\end{array}$ & $\begin{array}{r}0.1301 \\
(0.0722)\end{array}$ & $\begin{array}{r}-0.2635 \\
(0.1155)\end{array}$ & $\begin{array}{r}-0.3834 \\
(0.1035)\end{array}$ & $\begin{array}{r}-0.4500 \\
(0.1126)\end{array}$ \\
\hline$(t=+3)-(t=-1)$ & $\begin{array}{r}0.2305 \\
(0.0517)\end{array}$ & $\begin{array}{r}0.0590 \\
(0.0745)\end{array}$ & $\begin{array}{r}0.3277 \\
(0.0684)\end{array}$ & $\begin{array}{r}-0.2687 \\
(0.1011)\end{array}$ & $\begin{array}{l}-0.1164 \\
(0.1234)\end{array}$ & $\begin{array}{r}0.1926 \\
(0.0889)\end{array}$ & $\begin{array}{r}-0.3090 \\
(0.1520)\end{array}$ & $\begin{array}{l}-0.4441 \\
(0.1405)\end{array}$ & $\begin{array}{r}-0.4984 \\
(0.1535)\end{array}$ \\
\hline
\end{tabular}

a. CEO successions are classified: (1) by family ties: family when the incoming CEO was related by blood or marriage to the departing CEO, to a founder, or to a large shareholder of the corporation, and unrelated, otherwise; (2) by college "selectivity": selective college (SC), when the new CEO was reported to have attended a "very competitive" college or better in Barron's (1980) rankings, and less selective college (LSC), otherwise.

b. The measures of firm performance presented are based on: (A) operating return on assets (OROA): the ratio of operating income to the book value of assets, (B) industry-adjusted OROA: OROA less the median OROA of the relevant industry (two-digit SIC), (C) industry-and performance adjusted OROA, (D) industry-and performance adjusted net income to assets, and (E) industry-and performance adjusted Market-to-book ratios. Performance controls are created by dividing COMPUSTAT firms into deciles sorted by the relevant industry-adjusted variable in the year prior transition. The annual median of the relevant performance group of firms (ex-event) is then used as control. Time is measured in years relative to the year of the transition. The year of transition is omitted. Robust standard errors are reported in parentheses. 
TABLE 6. AlteRnATIVE DEFINITIONS OF “FAMILY” FiRMS

\begin{tabular}{|c|c|c|c|c|c|c|c|}
\hline \multirow[b]{2}{*}{ Sub-sample } & \multirow[b]{2}{*}{ All } & \multicolumn{2}{|c|}{ Type of Succession } & \multirow[b]{2}{*}{ Difference } & \multicolumn{2}{|c|}{ Family only } & \multirow{2}{*}{$\begin{array}{l}\text { Difference } \\
\text { Family=1 } \\
\text { SC vs LSC }\end{array}$} \\
\hline & & Family & Unrelated & & LSC & SC & \\
\hline & (I) & (II) & (III) & (IV) & (V) & (VI) & (VII) \\
\hline A. All CEO transitions & $\begin{array}{r}0.0071 \\
(0.0037) \\
{[335]}\end{array}$ & $\begin{array}{r}-0.0059 \\
(0.0056) \\
{[122]}\end{array}$ & $\begin{array}{r}0.0146 \\
(0.0049) \\
{[213]}\end{array}$ & $\begin{array}{c}-0.0205 \\
(0.0074)\end{array}$ & $\begin{array}{r}-0.0259 \\
(0.0092) \\
{[54]}\end{array}$ & $\begin{array}{r}0.0100 \\
(0.0064) \\
{[68]}\end{array}$ & $\begin{array}{r}-0.0359 \\
(0.0112)\end{array}$ \\
\hline $\begin{array}{l}\text { B. Ownership characteristics: } \\
\text { family ownership at least } \\
\text { five percent }\end{array}$ & $\begin{array}{r}0.0055 \\
(0.0044) \\
{[265]}\end{array}$ & $\begin{array}{r}-0.0066 \\
(0.0060) \\
{[111]}\end{array}$ & $\begin{array}{r}0.0142 \\
(0.0062) \\
{[154]}\end{array}$ & $\begin{array}{c}-0.0208 \\
(0.0086)\end{array}$ & $\begin{array}{r}-0.0289 \\
(0.0095) \\
{[51]}\end{array}$ & $\begin{array}{r}0.0124 \\
(0.0067) \\
{[60]}\end{array}$ & $\begin{array}{r}-0.0413 \\
(0.0117)\end{array}$ \\
\hline $\begin{array}{l}\text { C. Board characteristics: two } \\
\text { directors or more were related } \\
\text { by blood or marriage }\end{array}$ & $\begin{array}{r}0.0008 \\
(0.0051) \\
{[190]}\end{array}$ & $\begin{array}{r}-0.0065 \\
(0.0057) \\
{[120]}\end{array}$ & $\begin{array}{r}0.0132 \\
(0.0095) \\
{[70]}\end{array}$ & $\begin{array}{r}-0.0197 \\
(0.0111)\end{array}$ & $\begin{array}{r}-0.0259 \\
(0.0092) \\
{[54]}\end{array}$ & $\begin{array}{r}0.0094 \\
(0.0066) \\
{[66]}\end{array}$ & $\begin{array}{c}-0.0353 \\
(0.0113)\end{array}$ \\
\hline $\begin{array}{l}\text { D. Direct successions: incoming } \\
\text { and outgoing CEOs were } \\
\text { related by blood or marriage }\end{array}$ & & $\begin{array}{r}-0.0059 \\
(0.0065) \\
{[98]}\end{array}$ & & & $\begin{array}{r}-0.0246 \\
(0.0101) \\
{[48]}\end{array}$ & $\begin{array}{r}0.0120 \\
(0.0075) \\
{[50]}\end{array}$ & $\begin{array}{r}-0.0366 \\
(0.0125)\end{array}$ \\
\hline $\begin{array}{l}\text { E. Names: firm's name and } \\
\text { incoming CEO's last name } \\
\text { are the same }\end{array}$ & & $\begin{array}{r}-0.0132 \\
(0.0114) \\
{[38]}\end{array}$ & & & $\begin{array}{r}-0.0596 \\
(0.0187) \\
{[16]}\end{array}$ & $\begin{array}{r}0.0205 \\
(0.0094) \\
{[22]}\end{array}$ & $\begin{array}{r}-0.0802 \\
(0.0208)\end{array}$ \\
\hline
\end{tabular}

a. CEO successions are classified: (1) by family ties: family when the incoming CEO was related by blood or marriage to the departing $\mathrm{CEO}$, to a founder, or to a large shareholder of the corporation, and unrelated, otherwise; (2) by college "selectivity": selective college (SC), when the new CEO was reported to have attended a "very competitive" college or better in Barron's (1980) rankings, and less selective college (LSC), otherwise.

b. This table reports mean differences in three-year industry and performance adjusted operating return on assets (OROA): (three-year average after)-(three year average before) for alternative sub-samples of firms. Performance controls are created by dividing COMPUSTAT firms into deciles sorted by industry-adjusted OROA (two-digit SIC codes) in the year prior transition. The annual median of the relevant performance group of firms (ex-event) is then used as control for each firmyear.

c. Robust standard errors are reported in parentheses and the number of CEO successions is reported in square brackets. 


\section{Table 7. Alternative Selectivity Measures}

\begin{tabular}{|c|c|c|c|c|}
\hline \multirow[b]{2}{*}{ Alternative Sub-samples } & \multirow[b]{2}{*}{ All } & \multicolumn{2}{|c|}{ Type of Succession } & \multirow[b]{2}{*}{ Difference } \\
\hline & & Family & Unrelated & \\
\hline & (I) & (II) & (III) & $(\mathrm{IV})$ \\
\hline \multicolumn{5}{|l|}{ A. Groupings by college selectivity } \\
\hline $\begin{array}{l}\text { 1. Most Competitive Colleges: } \\
33 \text { Institutions }\end{array}$ & $\begin{array}{r}0.0104 \\
(0.0100) \\
{[51]}\end{array}$ & $\begin{array}{r}0.0019 \\
(0.0101) \\
{[22]}\end{array}$ & $\begin{array}{r}0.0169 \\
(0.0159) \\
{[29]}\end{array}$ & $\begin{array}{r}-0.0149 \\
(0.0189)\end{array}$ \\
\hline $\begin{array}{l}\text { 2. Highly Competitive Colleges: } \\
52 \text { Institutions }\end{array}$ & $\begin{array}{r}0.0061 \\
(0.0104) \\
{[30]}\end{array}$ & $\begin{array}{r}0.0131 \\
(0.0116) \\
{[15]}\end{array}$ & $\begin{array}{r}-0.0010 \\
(0.0174) \\
{[15]}\end{array}$ & $\begin{array}{r}0.0141 \\
(0.0209)\end{array}$ \\
\hline $\begin{array}{l}\text { 3. Very Competitive Colleges: } \\
104 \text { Institutions }\end{array}$ & $\begin{array}{r}0.0115 \\
(0.0084) \\
{[60]}\end{array}$ & $\begin{array}{r}0.0142 \\
(0.0110) \\
{[31]}\end{array}$ & $\begin{array}{r}0.0086 \\
(0.0129) \\
{[29]}\end{array}$ & $\begin{array}{r}0.0056 \\
(0.0169)\end{array}$ \\
\hline $\begin{array}{l}\text { 4. All U.S. colleges not included in the most, highly, or } \\
\text { very competitive categories }\end{array}$ & $\begin{array}{r}0.0061 \\
(0.0059) \\
{[148]}\end{array}$ & $\begin{array}{r}-0.0285 \\
(0.0101) \\
{[46]}\end{array}$ & $\begin{array}{r}0.0217 \\
(0.0068) \\
{[102]}\end{array}$ & $\begin{array}{r}-0.0502 \\
(0.0121)\end{array}$ \\
\hline 5. Observations with unreported or foreign institutions & $\begin{array}{r}0.0017 \\
(0.0099) \\
{[46]}\end{array}$ & $\begin{array}{r}-0.0109 \\
(0.0223) \\
{[8]}\end{array}$ & $\begin{array}{r}0.0043 \\
(0.0112) \\
{[38]}\end{array}$ & $\begin{array}{r}-0.0153 \\
(0.0241)\end{array}$ \\
\hline \multicolumn{5}{|l|}{ B. CEO transitions in group (A.4) by CEO's graduate school records } \\
\hline 1. No graduate studies were reported & $\begin{array}{r}-0.0020 \\
(0.0076) \\
{[94]}\end{array}$ & $\begin{array}{r}-0.0347 \\
(0.0133) \\
{[32]}\end{array}$ & $\begin{array}{r}0.0148 \\
(0.0085) \\
{[62]}\end{array}$ & $\begin{array}{r}-0.0495 \\
(0.0158)\end{array}$ \\
\hline 2. Graduate studies reported & $\begin{array}{r}0.0203 \\
(0.0093) \\
{[54]}\end{array}$ & $\begin{array}{r}-0.0143 \\
(0.0129) \\
{[14]}\end{array}$ & $\begin{array}{r}0.0324 \\
(0.0112) \\
{[40]}\end{array}$ & $\begin{array}{r}-0.0467 \\
(0.0170)\end{array}$ \\
\hline $\begin{array}{l}\text { Differences } \\
\text { (B.2) - (B.1) }\end{array}$ & $\begin{array}{r}0.0223 \\
(0.0120)\end{array}$ & $\begin{array}{r}0.0204 \\
(0.0185)\end{array}$ & $\begin{array}{r}0.0176 \\
(0.0141)\end{array}$ & $\begin{array}{r}0.0028 \\
(0.0231)\end{array}$ \\
\hline \multicolumn{5}{|c|}{ C. CEO transitions in group (A.4) by firms' research and development $(R \& D)$ activity prior transition } \\
\hline 1. No R\&D expenses reported in the year prior succession & $\begin{array}{r}0.0011 \\
(0.0069) \\
\text { [87] }\end{array}$ & $\begin{array}{r}-0.0230 \\
(0.0119) \\
{[34]}\end{array}$ & $\begin{array}{r}0.0166 \\
(0.0078) \\
{[53]}\end{array}$ & $\begin{array}{r}-0.0396 \\
(0.0142)\end{array}$ \\
\hline 2. Positive $R \& D$ expenses reported in the year prior succession & $\begin{array}{r}0.0133 \\
(0.0105) \\
{[61]}\end{array}$ & $\begin{array}{r}-0.0439 \\
(0.0192) \\
{[12]}\end{array}$ & $\begin{array}{r}0.0274 \\
(0.0114) \\
{[49]}\end{array}$ & $\begin{array}{r}-0.0712 \\
(0.0220)\end{array}$ \\
\hline $\begin{array}{l}\text { Differences } \\
\text { (C.2) - (C.1) }\end{array}$ & $\begin{array}{r}0.0122 \\
(0.0126)\end{array}$ & $\begin{array}{c}-0.0209 \\
(0.0223)\end{array}$ & $\begin{array}{r}0.0108 \\
(0.0138)\end{array}$ & $\begin{array}{r}-0.0317 \\
(0.0261)\end{array}$ \\
\hline
\end{tabular}

a. CEO successions are classified by family ties: family when the incoming CEO was related by blood or marriage to the departing CEO, to a founder, or to a large shareholder of the corporation, and unrelated, otherwise.

b. Panel A classifies firms based on the Barron's (1980) college selectivity rankings of the undergraduate institution attended by the incoming CEO.

c. Panels B and C only report firms classified in category four in Panel A. Panel B sub-divides these firms into two groups based on whether the incoming CEO was reported as having attended a graduate school, or not. Panel C sub-divides firms into two groups based on whether they reported research and development expenses in the year prior to the CEO transition.

d. This table reports mean differences in three-year industry- and-performance adjusted OROA as defined in Table 6 .

e. Robust standard errors are reported in parentheses and the number of CEO successions is reported in square brackets. 
TABle 8. Firm ChARACTERISTICS AND Alternative SUCCESSION DECISIONS

\begin{tabular}{|c|c|c|c|c|c|c|c|c|c|}
\hline & \multicolumn{9}{|c|}{ Alternative Succession Decisions } \\
\hline & \multicolumn{3}{|c|}{ Internal CEO } & \multicolumn{3}{|c|}{ Family CEO } & \multicolumn{3}{|c|}{ Family LSC CEO } \\
\hline & (I) & (II) & (III) & (IV) & $(\mathrm{V})$ & $(\mathrm{VI})$ & (VII) & (VIII) & (IX) \\
\hline Ln sales & $\begin{array}{l}-0.009 \\
(0.011)\end{array}$ & $\begin{array}{r}-0.010 \\
(0.010)\end{array}$ & $\begin{array}{r}-0.011 \\
(0.010)\end{array}$ & $\begin{array}{l}-0.010 \\
(0.021)\end{array}$ & $\begin{array}{l}-0.006 \\
(0.020)\end{array}$ & $\begin{array}{l}-0.009 \\
(0.020)\end{array}$ & $\begin{array}{c}-0.124 \\
(0.035)\end{array}$ & $\begin{array}{r}-0.102 \\
(0.033)\end{array}$ & $\begin{array}{l}-0.113 \\
(0.036)\end{array}$ \\
\hline Board ownership & $\begin{array}{r}0.046 \\
(0.096)\end{array}$ & $\begin{array}{r}0.052 \\
(0.093)\end{array}$ & $\begin{array}{r}0.049 \\
(0.094)\end{array}$ & $\begin{array}{r}0.073 \\
(0.153)\end{array}$ & $\begin{array}{r}0.082 \\
(0.153)\end{array}$ & $\begin{array}{r}0.062 \\
(0.152)\end{array}$ & $\begin{array}{r}-0.568 \\
(0.232)\end{array}$ & $\begin{array}{r}-0.449 \\
(0.221)\end{array}$ & $\begin{array}{r}-0.473 \\
(0.224)\end{array}$ \\
\hline Family directors & $\begin{array}{r}0.117 \\
(0.035)\end{array}$ & $\begin{array}{r}0.116 \\
(0.035)\end{array}$ & $\begin{array}{r}0.114 \\
(0.035)\end{array}$ & $\begin{array}{r}0.580 \\
(0.044)\end{array}$ & $\begin{array}{r}0.578 \\
(0.044)\end{array}$ & $\begin{array}{r}0.571 \\
(0.045)\end{array}$ & $\begin{array}{r}-0.006 \\
(0.151)\end{array}$ & $\begin{array}{r}0.003 \\
(0.152)\end{array}$ & $\begin{array}{l}-0.042 \\
(0.154)\end{array}$ \\
\hline $\begin{array}{l}\text { Industry adjusted } \\
\text { OROA }\end{array}$ & $\begin{array}{r}0.172 \\
(0.174)\end{array}$ & & & $\begin{array}{r}0.321 \\
(0.342)\end{array}$ & & & $\begin{array}{r}2.246 \\
(0.750)\end{array}$ & & \\
\hline $\begin{array}{l}\text { Industry adjusted market } \\
\text { to book ratio }\end{array}$ & $\begin{array}{r}0.021 \\
(0.022)\end{array}$ & $\begin{array}{r}0.002 \\
(0.021)\end{array}$ & $\begin{array}{r}0.002 \\
(0.021)\end{array}$ & $\begin{array}{r}-0.010 \\
(0.029)\end{array}$ & $\begin{array}{r}0.004 \\
(0.028)\end{array}$ & $\begin{array}{r}0.003 \\
(0.028)\end{array}$ & $\begin{array}{r}-0.025 \\
(0.045)\end{array}$ & $\begin{array}{r}0.019 \\
(0.043)\end{array}$ & $\begin{array}{r}0.014 \\
(0.042)\end{array}$ \\
\hline $\begin{array}{l}\text { High industry } \\
\text { adjusted OROA }\end{array}$ & & $\begin{array}{r}0.102 \\
(0.038)\end{array}$ & $\begin{array}{r}0.103 \\
(0.038)\end{array}$ & & $\begin{array}{r}-0.004 \\
(0.061)\end{array}$ & $\begin{array}{r}0.003 \\
(0.062)\end{array}$ & & $\begin{array}{r}0.189 \\
(0.104)\end{array}$ & $\begin{array}{r}0.231 \\
(0.110)\end{array}$ \\
\hline Positive $R \& D$ expenses & & & $\begin{array}{l}-0.021 \\
(0.034)\end{array}$ & & & $\begin{array}{l}-0.094 \\
(0.059)\end{array}$ & & & $\begin{array}{r}-0.213 \\
(0.100)\end{array}$ \\
\hline Number of observations & 335 & 335 & 335 & 335 & 335 & 335 & 122 & 122 & 122 \\
\hline Pseudo R2 & 0.066 & 0.096 & 0.097 & 0.312 & 0.311 & 0.316 & 0.115 & 0.079 & 0.105 \\
\hline
\end{tabular}

a. In Columns I to III, the dependent variable is internal succession (295 of 335 cases), equal to one if the succeeding CEO was hired by the corporation a year prior to succession or earlier, and zero otherwise. In Columns IV to VI the dependent variable is family (122 out of 335 cases), equal to one if the incoming CEO was related by blood or marriage to the departing CEO, to a founder, or to a large shareholder of the corporation, and zero otherwise. In Columns VII to IX the dependent variable is family LSC (54 out of 122 cases), equal to one if the succeeding CEO was a family member who was not reported to have attended a "very competitive" college or better in Barron's (1980) rankings or LSC in the text, and zero if the family successor attended a selective institution (SC). Columns VII to IX only report information for family transitions (122 cases).

b. Ln sales is the natural logarithm of sales in 2002 dollars. Board ownership is defined as the fraction of ownership held by officers and directors. Family directors is an indicator variable equal to one if the fraction of family to total directors is higher than the median of the firms in the sample, zero otherwise. Industry-adjusted operating return on assets (OROA) is the ratio of operating income to the book value of assets less the median OROA of the relevant industry (two-digit SIC). Industryadjusted market to book ratio is the ratio of the sum of the book value of assets plus the market value of equity minus the sum of the book value of equity and deferred taxes to the book value of assets, less the median of its industry. High industryadjusted OROA is an indicator variable equal to one if industry-adjusted OROA at $t=-1$ is above the median of the sample firms. Positive $R \& D$ expenses is an indicator variable equal to one if the firm reported research and development expenses in the year prior to the CEO transition, zero otherwise.

c. The table reports estimated changes in probabilities using a maximum-likelihood probit model. Robust standard errors are in parentheses. 
TABle 9. PERFormance ChANGES AROUnd SuCCESSIONS: REgRESSION ANALYSIS

\begin{tabular}{|c|c|c|c|c|c|c|c|c|c|c|}
\hline & \multicolumn{5}{|c|}{ Operating Return on Assets (OROA) } & \multicolumn{5}{|c|}{ Market to Book Ratios } \\
\hline & (I) & (II) & (III) & $(\mathrm{IV})$ & $(\mathrm{V})$ & $(\mathrm{VI})$ & (VII) & (VIII) & (IX) & $(\mathrm{X})$ \\
\hline Family CEO & $\begin{array}{r}-0.027 \\
(0.010)\end{array}$ & $\begin{array}{c}-0.015 \\
(0.013)\end{array}$ & $\begin{array}{c}-0.010 \\
(0.013)\end{array}$ & $\begin{array}{c}-0.039 \\
(0.015)\end{array}$ & $\begin{array}{c}-0.029 \\
(0.014)\end{array}$ & $\begin{array}{c}-0.248 \\
(0.089)\end{array}$ & $\begin{array}{c}-0.373 \\
(0.151)\end{array}$ & $\begin{array}{r}-0.004 \\
(0.111)\end{array}$ & $\begin{array}{r}-0.304 \\
(0.136)\end{array}$ & $\begin{array}{r}-0.220 \\
(0.119)\end{array}$ \\
\hline Family CEO * LSC & & & $\begin{array}{r}-0.037 \\
(0.015)\end{array}$ & & & & & $\begin{array}{r}-0.464 \\
(0.161)\end{array}$ & & \\
\hline$L S C$ & & & $\begin{array}{r}0.002 \\
(0.010)\end{array}$ & & & & & $\begin{array}{r}0.167 \\
(0.105)\end{array}$ & & \\
\hline Ln sales & $\begin{array}{r}0.001 \\
(0.003)\end{array}$ & $\begin{array}{c}-0.006 \\
(0.005)\end{array}$ & $\begin{array}{c}0.0003 \\
(0.003)\end{array}$ & $\begin{array}{r}0.001 \\
(0.004)\end{array}$ & $\begin{array}{r}0.003 \\
(0.003)\end{array}$ & $\begin{array}{r}0.046 \\
(0.036)\end{array}$ & $\begin{array}{r}0.101 \\
(0.073)\end{array}$ & $\begin{array}{r}0.039 \\
(0.035)\end{array}$ & $\begin{array}{r}0.061 \\
(0.045)\end{array}$ & $\begin{array}{r}0.084 \\
(0.044)\end{array}$ \\
\hline Industry adjusted OROA & $\begin{array}{c}-0.076 \\
(0.070)\end{array}$ & $\begin{array}{c}0.109 \\
(0.079)\end{array}$ & $\begin{array}{c}-0.064 \\
(0.070)\end{array}$ & $\begin{array}{c}-0.016 \\
(0.122)\end{array}$ & $\begin{array}{c}-0.018 \\
(0.123)\end{array}$ & $\begin{array}{r}0.052 \\
(0.613)\end{array}$ & $\begin{array}{c}-1.082 \\
(1.155)\end{array}$ & $\begin{array}{r}0.074 \\
(0.628)\end{array}$ & $\begin{array}{r}-0.222 \\
(0.903)\end{array}$ & $\begin{array}{r}-0.175 \\
(0.901)\end{array}$ \\
\hline Industry adjusted $M-B$ & $\begin{array}{c}-0.003 \\
(0.007)\end{array}$ & $\begin{array}{r}0.002 \\
(0.009)\end{array}$ & $\begin{array}{c}-0.003 \\
(0.007)\end{array}$ & $\begin{array}{c}-0.008 \\
(0.008)\end{array}$ & $\begin{array}{c}-0.008 \\
(0.008)\end{array}$ & $\begin{array}{r}0.525 \\
(0.295)\end{array}$ & $\begin{array}{r}1.079 \\
(0.211)\end{array}$ & $\begin{array}{r}0.499 \\
(0.289)\end{array}$ & $\begin{array}{r}0.337 \\
(0.336)\end{array}$ & $\begin{array}{r}0.372 \\
(0.313)\end{array}$ \\
\hline Board ownership & $\begin{array}{c}0.016 \\
(0.019)\end{array}$ & $\begin{array}{c}-0.005 \\
(0.032)\end{array}$ & $\begin{array}{r}0.010 \\
(0.019)\end{array}$ & $\begin{array}{r}0.022 \\
(0.025)\end{array}$ & $\begin{array}{r}0.024 \\
(0.024)\end{array}$ & $\begin{array}{r}0.064 \\
(0.215)\end{array}$ & $\begin{array}{c}-0.102 \\
(0.396)\end{array}$ & $\begin{array}{r}-0.017 \\
(0.210)\end{array}$ & $\begin{array}{r}0.097 \\
(0.309)\end{array}$ & $\begin{array}{r}0.091 \\
(0.297)\end{array}$ \\
\hline Family directors & $\begin{array}{r}0.009 \\
(0.010)\end{array}$ & $\begin{array}{r}0.011 \\
(0.013)\end{array}$ & $\begin{array}{r}0.009 \\
(0.010)\end{array}$ & $\begin{array}{r}0.004 \\
(0.012)\end{array}$ & $\begin{array}{r}0.002 \\
(0.012)\end{array}$ & $\begin{array}{c}-0.011 \\
(0.085)\end{array}$ & $\begin{array}{c}-0.078 \\
(0.157)\end{array}$ & $\begin{array}{c}-0.011 \\
(0.084)\end{array}$ & $\begin{array}{r}0.010 \\
(0.126)\end{array}$ & $\begin{array}{r}-0.010 \\
(0.124)\end{array}$ \\
\hline $\begin{array}{l}\text { Mean pre-transition industry and } \\
\text { performance adjusted OROA }\end{array}$ & $\begin{array}{l}-0.354 \\
(0.126)\end{array}$ & $\begin{array}{l}-0.849 \\
(0.159)\end{array}$ & $\begin{array}{l}-0.355 \\
(0.125)\end{array}$ & $\begin{array}{l}-0.299 \\
(0.166)\end{array}$ & $\begin{array}{l}-0.318 \\
(0.163)\end{array}$ & & & & & \\
\hline $\begin{array}{l}\text { Mean pre-transition industry and } \\
\text { performance adjusted } M-B\end{array}$ & & & & & & $\begin{array}{c}-0.454 \\
(0.231)\end{array}$ & $\begin{array}{c}-0.685 \\
(0.212)\end{array}$ & $\begin{array}{r}-0.422 \\
(0.228)\end{array}$ & $\begin{array}{r}-0.351 \\
(0.235)\end{array}$ & $\begin{array}{r}-0.361 \\
(0.221)\end{array}$ \\
\hline Governance index & & $\begin{array}{l}-0.001 \\
(0.002)\end{array}$ & & & & & $\begin{array}{r}-0.027 \\
(0.030)\end{array}$ & & & \\
\hline Graduate school & & & & $\begin{array}{r}0.015 \\
(0.015)\end{array}$ & & & & & $\begin{array}{r}0.343 \\
(0.154)\end{array}$ & \\
\hline Graduate school * family CEO & & & & $\begin{array}{c}-0.009 \\
(0.027)\end{array}$ & & & & & $\begin{array}{r}-0.588 \\
(0.223)\end{array}$ & \\
\hline Positive $R \& D$ expenses & & & & & $\begin{array}{r}0.020 \\
(0.013)\end{array}$ & & & & & $\begin{array}{r}0.373 \\
(0.127)\end{array}$ \\
\hline Positive $R \& D$ expenses $*$ family $C E O$ & & & & & $\begin{array}{r}-0.037 \\
(0.025)\end{array}$ & & & & & $\begin{array}{r}-0.751 \\
(0.267)\end{array}$ \\
\hline Number of observations & 335 & 115 & 335 & 194 & 194 & 335 & 115 & 335 & 194 & 194 \\
\hline R-squared & 0.142 & 0.340 & 0.163 & 0.217 & 0.225 & 0.170 & 0.448 & 0.191 & 0.330 & 0.346 \\
\hline
\end{tabular}

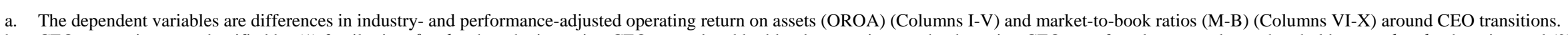

b. CEO successions are classified by (1) family ties: family when the incoming CEO was related by blood or marriage to the departing CEO, to a founder or to a large shareholder, unrelated, otherwise; and (2) by college "selectivity": selective college, when a CEO was reported to have attended a "very competitive" college or better in Barron's (1980) rankings, and less selective college (LSC), otherwise.

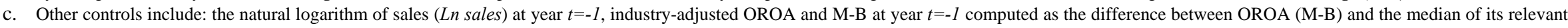
industry (two-digit SIC code), the fraction of ownership held by officers and directors (board ownership), an indicator variable equal to one (family directors) if the fraction of family to total directors is higher than the median in the sample, zero otherwise; mean pre-transition industry- and performance-adjusted OROA (M-B) is the three-year pre-transition average of the industry-and performance-adjusted OROA (M-B); governance index is from Gompers et al. (2003); graduate school is an indicator variable equal to one when the incoming CEOs was reported as having attended a graduate program, and zero otherwise; positive R\&D expenses is an indicator variable equal to one when the relevant firm reported positive research and development expenses the year prior to the CEO transition, and zero otherwise; and interactions between the indicator variables described above. All specifications include controls for year effects. Columns II and VII report information for those firms with matching governance indexes. Columns IV-V and IX-X report information for those firms classified as having a LSC CEO. Robust standard errors are in parentheses. 
TABle 10. Firm PERformanCe, CEO SEPARATION CONDITIONS AND OWNERSHIP

\begin{tabular}{|c|c|c|c|c|}
\hline (I) & (II & (III) & (IV & \\
\hline $\begin{array}{l}\text { Non- } \\
\text { retirements }\end{array}$ & $\begin{array}{l}0.0018 \text { Early CEO } \\
(0.0101) \text { succession }\end{array}$ & $\begin{aligned} 0.0007 & \text { Departing CEO } \\
\text { (0.0086) } & \text { remains as } \\
& \text { chairman }\end{aligned}$ & $\begin{array}{l}0.0045 \text { CEO ownership } \\
(0.0088)\end{array}$ & $\begin{array}{r}0.0203 \\
(0.0407)\end{array}$ \\
\hline Family CEO & $\begin{array}{l}\text {-0.0249 Family CEO } \\
(0.0098)\end{array}$ & $\begin{array}{l}\text {-0.0248 Family CEO } \\
\text { (0.0097) }\end{array}$ & $\begin{array}{l}\text {-0.0247 Family CEO } \\
(0.0099)\end{array}$ & $\begin{array}{r}-0.0263 \\
(0.0099)\end{array}$ \\
\hline
\end{tabular}

a. Dependent variable: difference in three-year industry- and performance-adjusted operating return on assets (OROA). Each column is a separate regression.

b. In Columns I-III, CEO successions are classified using indicator variables equal to one for: (1) non-retirements (75 cases) when the departing CEO was not reported to leave the firm due to a "retirement," zero otherwise; (2) early succession (126 cases) if the departing CEO left his position before age 65, zero otherwise; and (3) departing CEO remains as chairman (236 cases), if the departing CEO continued as chairman after the CEO transition, zero otherwise. In Column IV, CEO ownership is the ownership share of the entering CEO.

c. In all columns an indicator variable family takes the value of one for cases where the incoming CEO was related by blood or marriage to the departing CEO, to a founder or to a large shareholder of the corporation (122 out of 335 cases).

d. Additional controls (estimated coefficients not shown) in all regressions include: $\ln$ sales, at year $\mathrm{t}=-1$, industry-adjusted OROA and M-B at year t=-1, board ownership, family directors dummy, and mean three-year pre-transition industry- and performance adjusted OROA, as defined in Table 9. Robust standard errors are in parentheses.

TABLE 11. FIRM PERFORMANCE AND FAMILY CHARACTERISTICS

\begin{tabular}{|c|c|c|c|c|}
\hline (I) & (II) & (III) & (IV) & \\
\hline In-law CEO & $\begin{array}{l}0.009 \text { Female CEO } \\
(0.019)\end{array}$ & $\begin{array}{l}0.025 \text { Third or subsequent } \\
\text { (0.018) generation CEO }\end{array}$ & $\begin{array}{c}\text {-0.022 CEOs' and } \\
\text { (0.012) firms' names } \\
\text { are related }\end{array}$ & $\begin{array}{r}-0.014 \\
(0.012)\end{array}$ \\
\hline LSC-family CEO & $\begin{array}{l}-0.026 \text { LSC-family CEO } \\
(0.011)\end{array}$ & $\begin{array}{l}-0.026 \text { LSC-family CEO } \\
(0.011)\end{array}$ & $\begin{array}{l}-0.030 \text { LSC-family CEO } \\
(0.011)\end{array}$ & $\begin{array}{r}-0.026 \\
(0.011)\end{array}$ \\
\hline
\end{tabular}

a. Dependent variable: difference in three-year industry- and performance-adjusted operating return on assets (OROA). Each column is a separate regression.

b. The analysis concentrates on family successions only (when the incoming CEO was related by blood or marriage to the departing CEO, to a founder, or to a large shareholder), a total of 122 cases.

c. In Columns I-IV family successions are classified using indicator variables for: (1) in-law (seven observations) if the incoming CEO was related to the family by marriage but not by blood, zero otherwise; (2) female (four observations), zero otherwise, and (3) third or subsequent generation relative to the first family member that worked at the corporation (40 cases), zero otherwise. In Column IV an indicator variable takes the value of one for cases where the CEOs' and firms' names were the same (39 cases), and zero otherwise.

d. In all columns, an indicator variable $L S C$ equal to one is used for family CEOs who were not reported to have attended a "very competitive" college or better based on (1980) rankings (55 CEOs), zero otherwise.

e. Additional controls (estimated coefficients not shown) in all regressions include: $\ln$ sales, at year $\mathrm{t}=-1$, industry-adjusted OROA and $\mathrm{M}-\mathrm{B}$ at year $\mathrm{t}=-1$, board ownership, family directors dummy, and mean three-year pre-transition industry- and performance adjusted OROA, as defined in Table 9. Robust standard errors are in parentheses. 
TABle 12. Alternative Hypotheses And PeRformanCe MeAsures

\begin{tabular}{|c|c|c|c|c|c|c|}
\hline & \multicolumn{6}{|c|}{ Dependent Variables } \\
\hline & $\begin{array}{c}\text { Employment } \\
\text { / Assets }\end{array}$ & $\begin{array}{c}\text { Sale of PPE } \\
\text { / Assets }\end{array}$ & $\begin{array}{c}\text { R \& D } \\
\text { / Assets }\end{array}$ & $\begin{array}{c}\text { Net SGA } \\
\text { / Sales }\end{array}$ & $\begin{array}{c}\text { COGS } \\
\text { / Sales }\end{array}$ & $\begin{array}{c}\text { Sales } \\
\text { Growth }\end{array}$ \\
\hline & (I) & (II) & (III) & (IV) & $(\mathrm{V})$ & (VI) \\
\hline \multicolumn{7}{|c|}{ A. All CEO successions: grouped by family links } \\
\hline Family $C E O *$ after & $\begin{array}{c}0.00013 \\
(0.00066)\end{array}$ & $\begin{array}{c}-0.00144 \\
(0.00240)\end{array}$ & $\begin{array}{r}0.00461 \\
(0.00381)\end{array}$ & $\begin{array}{r}0.01510 \\
(0.00958)\end{array}$ & $\begin{array}{r}0.02069 \\
(0.00904)\end{array}$ & $\begin{array}{r}-0.00207 \\
(0.02059)\end{array}$ \\
\hline After & $\begin{array}{r}0.00071 \\
(0.00106)\end{array}$ & $\begin{array}{c}0.00186 \\
(0.00170)\end{array}$ & $\begin{array}{c}-0.00733 \\
(0.00415)\end{array}$ & $\begin{array}{c}-0.01905 \\
(0.00844)\end{array}$ & $\begin{array}{c}-0.00194 \\
(0.00953)\end{array}$ & $\begin{array}{r}-0.02234 \\
(0.01488)\end{array}$ \\
\hline Family CEO & $\begin{array}{c}-0.00587 \\
(0.00452)\end{array}$ & $\begin{array}{r}0.00117 \\
(0.00195)\end{array}$ & $\begin{array}{c}-0.01396 \\
(0.00735)\end{array}$ & $\begin{array}{c}-0.01554 \\
(0.01595)\end{array}$ & $\begin{array}{c}-0.00469 \\
(0.01732)\end{array}$ & $\begin{array}{r}-0.01280 \\
(0.01666)\end{array}$ \\
\hline Firm-years & 1,992 & 1,515 & 1,068 & 1,041 & 2,003 & 1,998 \\
\hline Number of firms & 335 & 299 & 188 & 184 & 335 & 335 \\
\hline \multicolumn{7}{|c|}{ B. Family successions only: grouped by college selectivity } \\
\hline LSC CEO * after & $\begin{array}{r}0.00005 \\
(0.00065)\end{array}$ & $\begin{array}{r}0.00385 \\
(0.00430)\end{array}$ & $\begin{array}{c}-0.00275 \\
(0.00570)\end{array}$ & $\begin{array}{r}0.02875 \\
(0.02480)\end{array}$ & $\begin{array}{r}0.03017 \\
(0.01629)\end{array}$ & $\begin{array}{r}-0.07484 \\
(0.03213)\end{array}$ \\
\hline After & $\begin{array}{r}0.00092 \\
(0.00075)\end{array}$ & $\begin{array}{c}0.00085 \\
(0.00181)\end{array}$ & $\begin{array}{r}0.00272 \\
(0.00607)\end{array}$ & $\begin{array}{c}-0.01546 \\
(0.01560)\end{array}$ & $\begin{array}{r}0.01129 \\
(0.01066)\end{array}$ & $\begin{array}{r}0.01448 \\
(0.01776)\end{array}$ \\
\hline$L S C C E O$ & $\begin{array}{r}0.00099 \\
(0.00152)\end{array}$ & $\begin{array}{c}0.00429 \\
(0.00394)\end{array}$ & $\begin{array}{c}-0.01268 \\
(0.01037)\end{array}$ & $\begin{array}{r}0.00289 \\
(0.02647)\end{array}$ & $\begin{array}{r}0.00926 \\
(0.02789)\end{array}$ & $\begin{array}{r}0.05793 \\
(0.02601)\end{array}$ \\
\hline Firm-years & 725 & 579 & 302 & 302 & 729 & 728 \\
\hline Number of firms & 122 & 113 & 55 & 55 & 122 & 122 \\
\hline
\end{tabular}

a. Dependent variables: (I) ratio of employees (thousands) over assets (millions), (II) ratio of sales of property, plant, and equipment (PPE, millions) over assets, (III) ratio of expenses in research and development (R\&D, millions) over assets (millions), (IV) net selling, general and administrative expenses (SGA, millions) over sales, where net SGA are defined as gross SGA minus R\&D expenses, (V) ratio of cost of goods sold (COGS, millions) over sales, and (VI) annual growth in sales (2002 dollars). All specifications include controls for year effects.

b. In Panel A, an indicator variable $(1,0)$ family is used for cases where the incoming CEO was related by blood or marriage to the departing CEO, to a founder or to a large shareholder of the corporation (122 out of 335 observations), and unrelated, otherwise. After is an indicator variable that takes the value of one in the post-succession period. The year of transition is omitted.

c. Panel B analyzes family successions only and the indicator variable $L S C(1,0)$ is used for CEOs who were not reported to have attended a "very competitive" college or better based on (1980) rankings (55 CEOs out of 122).

d. Data for a three-year window around CEO successions are used, where available. The year of transition is omitted.

e. Clustered (firm) standard errors are reported in parentheses. 
Excluded observations:

Observations with employment equal to zero or sales, assets or market value less than one

million dollars

Observations with unidentified founding dates ${ }^{\mathrm{b}}$

Firms founded before $1971^{\mathrm{c}}$

Information from proxy statement/news searches did not show: (1) at least one shareholder with five percent of shares, (2) two or more individuals related by blood or marriage reported as shareholders, officers or directors, (3) a founder as incumbent CEO $^{\mathrm{d}}$

No management change reported in news search (up to 1/1/2001) or missing financial data at the time, at years $t=-1$ or $t=+1$ around management change (e.g. Pre-IPO)

Preceding or new CEO did not hold the position for at least two years ${ }^{\mathrm{e}}$

Management transition reported between founders or siblings ${ }^{f}$

a. Financial and utility firms were excluded due to regulations that may affect results.

b. Information on founding dates was gathered using (1) Dun's Million Dollar Directory (various years), (2) firms' annual reports, (3) news searches using the Dow Jones Factiva tool, and (4) web searches.

c. I concentrated on firms founded before 1971 to increase the likelihood of observing a "normal" non-performance driven management change.

d. This restriction aimed at limiting the sample to firms where control was likely to be passed among family members.

e. This restriction filtered out interim or multiple successions where it was particularly hard to attach firm performance to one particular CEO.

f. This restriction was introduced for ease of classification since founders or siblings are not children nor are they unrelated to departing CEOs. 